\title{
Coastline evolution of the Portuguese south eastern coast: a high-resolution approach in a 65 years' time-window
}

\author{
Sílvia Nave ${ }^{1}$ (D) Luís Rebêlo $^{1}$ \\ Received: 21 September 2020 / Revised: 7 December 2020 / Accepted: 10 December 2020 / Published online: 9 January 2021 \\ (C) The Author(s), under exclusive licence to Springer Nature B.V. part of Springer Nature 2021
}

\begin{abstract}
The coast, as the interface between land and sea, is a highly dynamic area, endangered by erosion and flooding, particularly at times of sea-level rise. At the present context of climate change, the use of scientific knowledge to understand coastal dynamics and coastal evolution assessment through time is essential to find a suitable management response for a successful adaptive coastal governance. It is proposed that the obtained high-resolution and long-term coastline change dataset is of crucial importance to improve the knowledge on mesoscale evolution of the Portuguese south-eastern coast, from Ancão to Vila Real de Santo António (VRSA), a $55 \mathrm{~km}$ long coastal stretch.

The evolutionary trend, from 1950 to 2015, points to a general seaward progradation at the western (Barreta island) and eastern (Cacela peninsula - VRSA) sectors, and mostly an erosional trend at the central barrier island system (Culatra, Tavira and Cabanas islands). Moreover, a considerable average landward displacement of approximately $130 \mathrm{~m}$ is observed at Cabanas island.

Regarding overall coastline movement, seaward displacement prevails, with a prograding coastline occupying approximately $54 \%$ of the studied sector even though this is mostly associated with human intervention on the coast. The exception is the Manta Rota - Monte Gordo sector where accumulation is likely related to natural processes.

Considering the significant influence man-made interventions have had on the coastline evolution, it is believed that the natural evolutionary pattern would point to an overall erosional trend in the islands sector and a progradational trend from Manta Rota to VRSA beach.
\end{abstract}

Keywords Coastline evolution mapping $\cdot$ Coastal erosion and accretion $\cdot$ Barrier islands $\cdot$ SE Portuguese coast $\cdot$ Algarve $\cdot$ Digital shoreline analysis system (DSAS)

\section{Introduction}

As shown by the recent geological record, the coastline position is extremely variable, in space and time, being largely controlled by sea-level variations associated to natural climate changes. Sea-level oscillations ranging from $130 \mathrm{~m}$ below than the current level, during the last glacial maximum (c.a.

Sílvia Nave

silvia.nave@lneg.pt

Luís Rebêlo

luis.rebelo@lneg.pt

1 Laboratório Nacional de Energia e Geologia, IP (LNEG) - Unidade de Geologia, Hidrogeologia e Geologia Costeira, Estrada da Portela. Bairro do Zambujal. Apartado 7586, Alfragide,

2610-999 Amadora, Portugal
18,000 years ago), to $6 \mathrm{~m}$ above the current level, at the last interglacial period (c.a. about 130,000 years ago) (Waelbroeck et al. 2002), have led to a highly variable and dynamic shoreline position. Moreover, despite natural variations, coastal areas are currently endangered as the rate of sea level rise since the mid-nineteenth century, likely influenced by anthropogenic factors, has been greater than the mean rate during the previous two millennia (IPCC 2014).

Notwithstanding the fact that large variation of the shoreline position is expected in a longer time-frame, particularly on the transient landscapes of barrier islands, the permanent human occupation of coastal areas which exists, and will exist, hampers the natural dynamics of the system within human and economic time-scales of decades to centuries (Ferreira et al. 2008; McNamara and Lazarus 2018; Schmidt et al. 2013; Vousdoukas et al. 2020). The latest projections of the Intergovernmental Panel on Climate Change (IPCC), which point to the rise between $0.26 \mathrm{~m}$ and $0.82 \mathrm{~m}$ of the global sea 
level by the end of this century (IPCC 2014), become a massive challenge, considering the permanent and densely populated coastal areas that will need a proper and effective defence (Ferreira et al. 2008; Vousdoukas et al. 2020).

The implementation of short-term adaptive measures has somehow limited the threat of coastal erosion and flooding. However, the assessment of coastal retreat rates and the understanding of the shore evolution is needed for the planning and implementation of effective adaptive measures, locally and worldwide.

The Portuguese continental coast, with an approximately extension of $900 \mathrm{~km}$, has a variety of geological environments, which will react differently to an accelerated sealevel rise. The eastern southern Portuguese coast, the focus of this work, is a low-lying sandy shore with a complex barrier island system, a particular geomorphological feature, giving rise, at its easternmost part, to a continuous sandy beach that culminates at the Guadiana river mouth (Fig. 1).

The Ria Formosa barrier system plays an important role on the protection of several habitats, such as salt marshes, dunes, lagoon marshes and associated intertidal environments. Coastal vulnerability, in this area, is extremely high as the barrier island shoreline is exposed to many natural and maninduced threats, namely, storm erosion, sediment longshore drift reduction, sea level rise and anthropogenic induced factors (e.g. groins, seawalls, channel and inlet position fixation, dune destruction, and others). In the present context of climate change, many of these threats to coastal areas, and in particular in the Ria Formosa, are likely to increase in the near future. Previous studies focusing on the evolution of the Ria Formosa coastal system revealed the existence of several vulnerable areas. These areas have very dynamic processes, specifically, extremely high evolution rates of islands and inlets (Dias et al. 2004; Teixeira 2009). The evolution of the Ria Formosa barrier island is governed by two major key mechanisms. The onshore progression of the islands and the longshore drift from west to east. These two mechanisms have geomorphological and environmental implications and, as they act at a human time-scale, they greatly affect human occupation in the coast, even though the evolution analysis time-scale is longer in the onshore inland displacement.

Sea-level rise, storm increase and shortening in longshore sediment drift may drastically affect the overall system, leading to coastal erosion and greater overwash susceptibility (Dias et al. 2004; Matias 2006), and to the fastening of the onshore migration of the islands. Besides overwash effect, massive sand intrusion, due to barrier breaching and inlet overture, is also likely to occur more frequently.

Severe changes in the barrier island complex will also have an impact on the internal part of Ria Formosa system which already shows, an intensification of the silting-up of the lagoon, due to strong anthropogenic pressure. Corrective interventions are required to minimize these threats (Ceia et al. 2010; Dias et al. 2004).

The valuable knowledge on long-term coastal evolution of the barrier islands, at a high-resolution scale, needs to be integrated in the coastal management so as to achieve an effective adaptive coastal governance of this particular sector (Ceia et al. 2010; Ferreira et al. 2008). In order to obtain this important information, a coastal evolution assessment of the continuous shoreline fringe from Vila Real de Santo António to Ancão peninsula (Faro) over a 65 -year period, with a 10 -year interval,

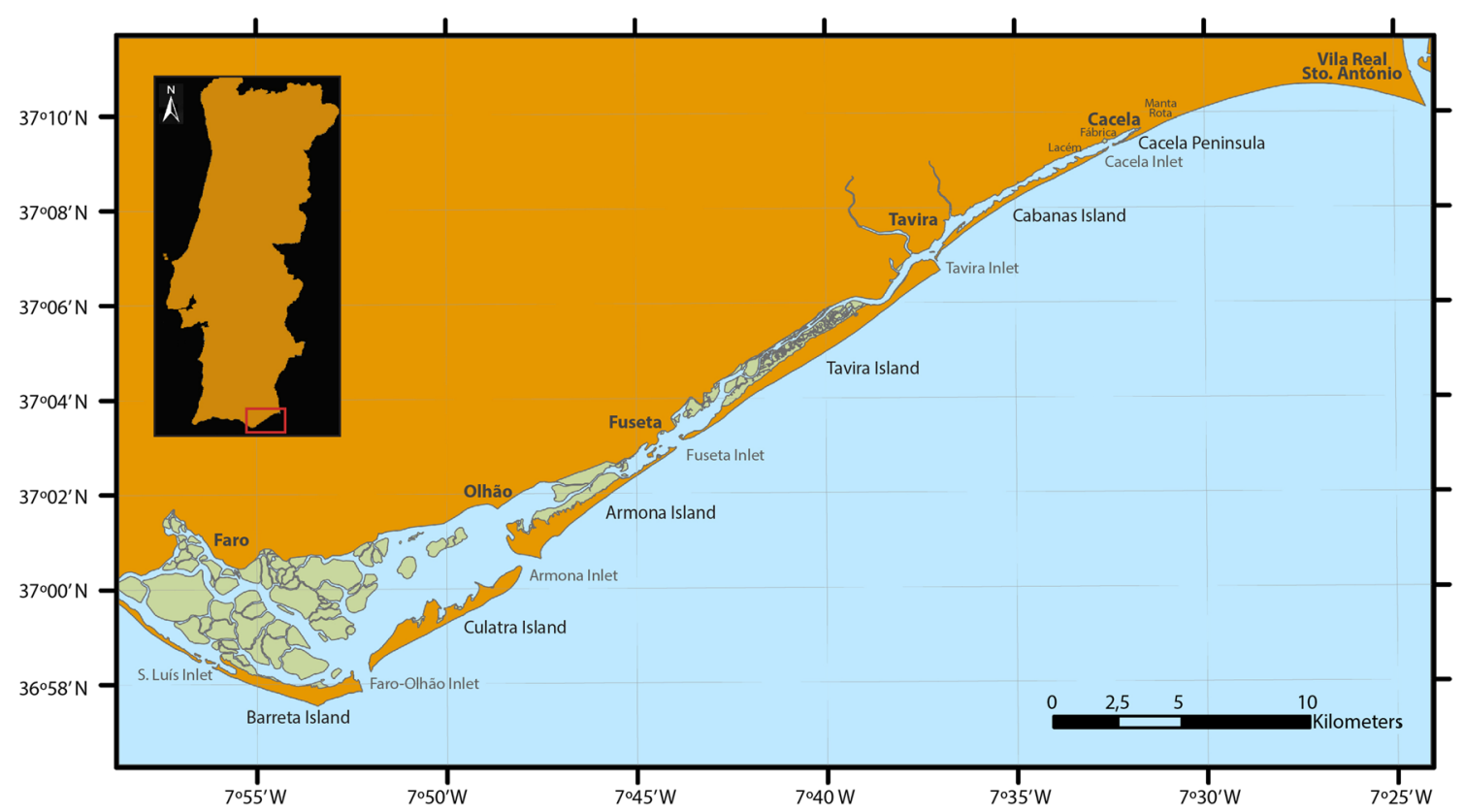

Fig. 1 Study area: the south-eastern Portuguese coast, with the barrier island system, giving place, at the easternmost part, to a continuous sandy shore that culminates at the Guadiana river mouth 
has been carried out and will be presented in this paper. This work was done within the "Geological and Coastal Hazard Mapping at a 1:3000 resolution scale" programme, developed by the Portuguese National Laboratory of Energy and Geology (LNEG) (Nave and Rebêlo 2018), which has the objective of cover the whole continental Portuguese coast.

\section{Regional setting}

The eastern coastal sector of the southern Portuguese region is characterized by the Ria Formosa barrier island system which is followed by a low lying sandy coastal plain, that extends from Manta Rota to Vila Real de Santo António (VRSA) (Fig. 1).

The barrier island system, extending over $50 \mathrm{~km}$, is composed by two peninsulas (Ancão and Cacela), the western and eastern limits of the system respectively, and five barrier islands, namely, from west to east, Barreta, Culatra, Armona, Tavira and Cabanas. The connection between the ocean and the back barrier zone is made through six tidal inlets (São Luís, Faro-Olhão, Armona, Fuseta, Tavira and Cacela inlets) (Fig. 1). These acts as the gateways for sedimentary, hydraulic, chemical and nutrient transport between the ocean and an $84 \mathrm{~km}^{2}$ lagoon complex, with a typical morphology and dynamic structure, comprising marshes, tidal channels, islets and tidal flats (Andrade 1990).

Similar to other transgressive barrier island systems, Ria Formosa is in an active phase of landward migration, presumably as a response to sea level rise. Oceanic overwashes are extremely important in this process (Dias 1988; Pilkey et al. 1989). Island erosion and rebuilding in a more onshore position is another process of landward migration. Although the system is retreating, the longitudinal growth rates of some islands are clearly notable.

Regarding marine forcing mechanisms, the coast adjacent to the Guadiana estuary is semidiurnal mesotidal, with average tidal amplitudes of around $2 \mathrm{~m}$ (Garel et al. 2015). At high tide, saline coastal waters penetrate about $40 \mathrm{~km}$ upriver. The offshore coastal wave regime is primarily dominated (approximately $50 \%$ of occurrences), by waves from $\mathrm{W}$ and SW followed by SE waves approximately with $25 \%$ of occurrences.

The morphodynamics in the Ria Formosa barrier island system varies according to the maritime agitation and tidal currents (Pilkey et al. 1989). Tides are semidiurnal mesotidal. Maximum ranges reached by spring tides, of $3.2 \mathrm{~m}$, approach the maximum range limit for barrier island formation (Pilkey et al. 1989). The west flank is more energetic to being under the direct influence of the dominant wave conditions, predominantly from the WSW. The eastern side is exposed, about $29 \%$ of the time, to "Levante" conditions (SE Mediterranean wind), which originate SE waves (Costa 1994). The predominant wave regime and the angular relationship of the waves with the shoreline orientation generates a net littoral drift, from west to east, forcing the position of the inlets to move in the same direction. This migration results from the sedimentary accumulation on the barrier island west of the bar, forcing the opening to migrate towards the east. Inlets mostly show eastward movement until a limiting position is reached, then infilling of the inlet occurs and a new cycle starts with the opening of a new inlet in a position close to the initial one (Weinholtz 1978). Thus, the position of the tidal inlets, when natural, is highly dynamical through time. The exception is the Armona inlet, the only naturally stable inlet (Weinholtz 1964; Pilkey et al. 1989), which has occupied a constant position throughout recent centuries, although its width has considerably decreased (Andrade 1990; Weinholtz 1964; Dias 1988; Salles 2001).

The western sector of the Ria Formosa barrier islands, between Ancão and the Faro - Olhão inlet, is exposed to the dominant coarse swell and corresponds to a section conditioned by sedimentary sources located to the west (the erosion result of the sandy cliffs of the sector between Falésia beach and Garrão), by sedimentary processes of a transversal nature, and also presently, by sediments derived from artificial beach nourishments at Ancão Peninsula. The barrier of Ancão peninsula, consisting of a beach and a single dune body, is extremely sensitive to erosive processes such as the ones related to overwash processes and seasonal variation of the beach profile (Andrade 1990; Matias 2006). The Ancão inlet, currently with a dynamic drifting, is in an advanced state of silting, having experienced an extremely rapid evolution since the artificial opening in 1997 (Teixeira 2009; Vila-Concejo et al. 2002).

The Faro - Olhão inlet, presently the most important inlet, was artificially opened and initially stabilized with jetties in 1929, structures that where completed in 1955 (Esaguy 1984; Esaguy 1986). This new inlet introduced a series of changes to the system that still persist today (Teixeira 2009). The construction of rigid structures led to changes in the sedimentary balance of the adjacent beaches, with erosion eastwards and accumulation westwards. The inlet channel has severely deepened, reaching more than $40 \mathrm{~m}$ in depth (Teixeira 2009). The increase in the cross-section of the bar led to an intensification in the flow capacity, subordinating the remaining inlets of the system, in particular the Armona inlet (until then the most important one), which acquire a tendency towards silting up (Andrade 1990; Teixeira 2009).

The Culatra island experienced noteworthy changes, having triplicated its extension, in the last century, through the growth of successive beach ridges (Andrade 1998) resulting from the incorporation of sediments released by the tidal delta of the Armona inlet (Andrade 1990). The hindrance to the coastal drift induced by the jetties of the Faro - Olhão inlet, triggered erosion at Farol beach, forcing the deployment of coastal defence structures (Teixeira 2009). 
The central sector, comprising the Armona and Tavira islands, is the one with the greatest stability, although important changes are associated with the Fuseta inlet dynamics (Teixeira 2009). In the last decades, the Fuseta inlet, which separates both islands, has migrated eastwards along a fringe of more than $3000 \mathrm{~m}$ (Andrade 1990; Vila-Concejo et al. 2006) and, as a consequence, a growing of the eastern tip of Armona island and an erosion of the western tip of Tavira island have occurred. The evolution of the Tavira island coastline shows relative stability, with a tendency of accretion at its eastern end associated with the hurdle effect induced by the western jetty of the Tavira inlet (Hidroprojecto 1998), and erosion on the western tip, associated with the inlet migration.

The segment between the actual Tavira and Cacela inlets has suffered a rapid evolution, with a sequence of important physiographic transformations (Teixeira 2009). The Tavira inlet was artificially opened between 1930 and 1935 . However, due to natural silting up processes, a new opening was performed in 1961, with the extension of the jetties, work that ended in 1977 (Esaguy 1987; Teixeira 2009, and references therein). This infrastructure has a significant impact in the longshore drift causing the sedimentary balance to be positive to the west, with sands accumulation against the west jetty, and negative to the east, as observed in Faro inlet, causing erosion at the western limit of the Cabanas island. Currently, the Tavira inlet tends towards silting, being subjected to frequent dredging operations (Teixeira 2009).

The recently formed Cabanas island also underwent severe adjustments, triggered either as a result of the artificial opening of the Tavira inlet, or by the cyclone of 1941, which caused a series of modifications in the barrier island system (Teixeira 2009). The Cabanas island was almost destroyed in that extreme event and in the storms of 1961 (Esaguy 1987), which explains its narrow extension and incipient dune body, albeit with a later tendency for growth (Hidroprojecto 1998). The palisades, of about $1.5 \mathrm{~m}$ in height, placed in the embryo dunes, in 2002, by the Ria Formosa Natural Park, are already totally covered by robust dune buildings, that have accumulated (Teixeira 2009).

The recent evolution of Cacela's Peninsula is related to the significant hydrological and sedimentary changes that occurred due to the Manta Rota inlet closure (during the first half of the last century), when the last island of the system welded to land, becoming a peninsula. Following, the western shift of the existent inlet (presumably to the Cabanas area) and the associated silting of the lagoon related to the multiple overtures that occurred since then (between Lacém and Cacela), entailed a shortening of sediment supply to the place of the actual peninsula. As a consequence, the Cacela peninsula, which was narrow and with incipient dune systems, has undergone substantial changes (Teixeira 2009). With a precarious balance, the western part of the peninsula has, since the early 1950 s, been literally swept away by the migration of tidal inlets. In the winter season of $1995 / 96$, following the occurrence of a storm swell, a new inlet naturally opened in front of the Fábrica local village (Dias et al. 2004). In 2003, to reverse this eastward migration trend, a new artificial inlet was opened westwards (Vila-Concejo et al. 2006) next to the Lacém site, while the natural inlet was closed and an artificial dune put in its place. The new Lacém inlet moved again to the Fábrica Village and began to suffer severe silting. With the narrowing of the peninsula towards the eastward of the inlet, particularly in face of Cacela Velha village, as a consequence of the sediment sink due to the lagoon's continuous silting, dune erosion and overwash processes became more frequent. A new artificial opening of an inlet was then made, in 2010, slightly to the east of Cacela, making the peninsula even shorter (Rebêlo and Nave 2018). This new inlet acted again as a sediment sink, while as the lagoon silting took place, reducing the littoral sand drift to the east, and thus resulting in an increase of erosion and in the narrowing of the remaining peninsula.

The changes experienced in the Cacela peninsula had, and continue to have, a significant impact on the eastern sector, namely at Manta Rota beach, which has undergone very significant changes in the last 60 years (Rebêlo 2004; Teixeira 2009). Significant beach progradation and a well-developed foredune sequence occurred, as a result of the coastline alignment after the Manta Rota inlet closure (Rebêlo 2004). Plenty of sediment was available to fulfil the littoral potential drift while the very long peninsula (from Cabanas to Manta Rota) was being eroded.

Eastwards of Manta Rota and up to the mouth of the Guadiana river, the coast is dominated by fine sand beaches supported by generally stable dune bodies with considerable width (Teixeira 2009). This is a stable littoral sector characterized by its tendency to accumulate sediments derived from westward coastal drift. (Teixeira 2009).

The final eastward coastal sector is characterized by an intense accumulation of sand that culminates at the Guadiana river. In its last $7 \mathrm{~km}$ of the mainland it crosses an open coastal plain, part of an old deltaic plain dominated by marsh systems formed by the river (Morales 1997). Coastal morphology and coastline position have significantly changed in the past decades. Relevance should be given to the anthropogenic modifications of the Guadiana river discharge and by the retained accumulation of sand by the west jetty of Guadiana river, completed in 1976 (Dias and Taborda 1998). Although the natural trend was already showing a prograding behaviour (Garel et al. 2015), the jetty construction played an important role in defining the present morphology and coastline position.

Beach and dunes environments are usually affected by water streams flowing into the ocean. If, in the western part of the study area, the rivers influence is distant from the coastline, since the islands are far away from the shore, in the eastern 
part, the surface drainage impacts the coastal morphology and, in turn, is affected by coastal geological processes. At a smaller scale, the regional geology and the proximity of the Guadiana River basin have a role in hampering the river flow directly into the sea. However, at a more detailed scale analysis, eastward Ria Formosa, north-south surface drainage is highly influenced by coastal barriers and sand dunes.

To the east of Cabeço beach, the VRSA dune field, which separates the Guadiana estuary from the sea, acts as a barrier to surface drainage, deflecting the runoff directly into the Castro Marim marsh and Guadiana river. Between Cabeço beach and the beginning of Cacela peninsula, which corresponds to the final part of the barrier system, the streams flow directly into the sea. The existent rivulets have seasonal and intermittent flows and are associated with small catchment areas. However, large floods may occasionally occur, associated with intense local precipitation. Of the four main rivulets, two flow into Manta Rota, the Álamo stream, which flows to the west of Altura and the Vale Põe Água stream, which flows between the Altura and Cabeço.

At Manta Rota, the rivulets discharge into the sea is conditioned by the existing coastal morphology generated by the fast beach growth. Low-level surfaces, formed from wind deflated beaches and non-continuous foredune ridges morphologies, were sealed by more recent and continuous foredune ridges. This particular environment was prone to flooding during heavy rain periods, creating temporary water sheds. This way, because of the existing continuous foredune ridges, water discharge, following the lower altitude surface, tends to occur westward, towards the lagoon system, instead of flowing directly into the ocean. As a consequence, and because there is no dune breaching, sand remobilization occurs into the lagoon. The Álamo stream denotes a wider and more developed alluvium compared to Põe Água, probably due to a larger catchment basin. In both cases, breaching of existing coastal barriers was the natural process of water drainage, as shown by dune morphology. Nowadays, at the mouth of Álamo stream, a submarine outfall was recently built, under the dunes, which ensures fluvial discharge directly to the underwater area of the beach, without breaking the barrier (Teixeira 2009).

\section{Methodology}

\section{Coastline indicator}

The criteria applied for shoreline definition was the one described in Nave and Rebêlo 2018 and references therein. Thus, since the aim of this current work is to provide quantitative data on the long-term ( $>60$ years) coastline evolution, with high resolution, the foredune baseline was used as a marker of the coastline in order to exclude short-term (tidal) or medium-term (seasonal) variations.

The coastline position was smoothly marked at the maximum scale of 1: 800 to better identify the outer limit of the dune zone. Interruptions in the vegetation line of less than approximately $150 \mathrm{~m}$ were not considered, maintaining the continuity of the line of the adjacent segment. In the case of settlements, or large infrastructures, that prevented the natural development of the foredune, the continuity of the line of adjacent segments (prior to and after the interruption) was also considered (Rebêlo and Nave 2019), attempting to maintain the coastline, where the coast shows some curvature, parallel to the wet/dry line.

In order to determine the error associated with the operator, for each year, the coastline was marked by two different operators using the same criteria. The coastline used for each year thus corresponds, to the average position of the lines calculated between the two operators (Rebêlo and Nave 2019).

\section{Data sources}

Aerial photographs and ortophotos from nine different years, from the flights SPLAL (1950), USAF (1958), CiGEO (1972), FAP (1980), DGT (1985), DGT (1991), DGT (2005), DGT (2010), DGT (2015), were used in order to allow a near-decadal analysis. The data was provided by the Direcção Geral do Território and by the CiGEO (Army Geospatial Information Center). The non-digital aerial photos were scanned at 1200 dpi subsequently creating mosaics with the Adobe Photoshop CS6 image software. This was done with the aim to expedite the georeferencing process, since it prevents links duplication between the overlap area of two consecutive aerial photos (Rebêlo and Nave 2019). Additionally, given that each link creation on the scanned image leads to uncertainties of a similar magnitude to the accuracy of the orthophoto, the use of mosaics, also reduces georeferencing errors.

The georeferencing process was carried out for 1950, 1958, 1972, 1980, 1985 and 1991 flights based on the 2015 orthophotos (the most recent one available at the date this work was done), using ArcMap, a module from ArcGIS(C) Desktop 10.6.1 of ArcGIS® software by Esri. ${ }^{1}$

Since the objective was the digitization of the coastline, a greater focus on the georeferencing process, reflected in a greater number of links, was implemented in the area next to the coastline. The links were created with a zoom view, with a scale of 1: 400, 1: 600 or, at most, 1: 800. The image interpolation was done using the Spline method (Rebêlo and Nave

\footnotetext{
${ }^{1}$ ArcGIS $®$ and ArcMap ${ }^{\mathrm{TM}}$ are the intellectual property of Esri and are used herein under license. Copyright $\odot$ E Esri. All rights reserved. For more information about Esriß software, please visit www.esri.com.
} 
2019). Control points were marked in the 2015 and in the nonrectified images, also with zoom, to determine georeferencing errors after the process completion.

\section{Mapping procedures and DSAS calculation of coastline evolution}

After obtaining the average coastline position for each of the nine historical aerial photographs, the shoreline evolution was calculated using the Digital Shoreline Analysis System (DSAS) Software, which is an add-in within the Environmental System Research Institute (ESRI) ArcGISC ArcGIS desktop v. 10.410.6. This software enables the calculation of a range of statistical change measures, derived within DSAS, based on the comparison of shoreline positions through time (Himmelstoss et al. 2018); (https://www.usgs.gov/centers/whomsc/science/ digital-shoreline-analysis-system-dsas?qt-science_center_ objects=0\#qt-science_center_objects).

DSAS software has been highly used and shown to be an effective tool for transforming the surveyed coastline into a data matrix of distance measurements from which temporal and spatial changes are determined for many different environments (e.g. Oyedotun 2014; Lira et al. 2016). For this work, DSAS allowed us to calculate coastline changes based on the measured differences between nine shoreline positions associated with the analysed time periods (1950, 1958, 1972, 1980, 1985, 1991, 2005, 2010, 2015), producing three parameters:

(i) Shoreline Change Envelope (SCE), a measure of the total change in coastline movement, considering all available shoreline positions and reporting their distances, without a reference to their specific dates;

(ii) Net Shoreline Movement (NSM), corresponding to the distance between the oldest (in this case, 1950) and the youngest coastline (2015). For the present work the NSM refers to an overall time frame of 65 years;

(iii) Linear Regression Rate (LRR), a statistical parameter determines a rate-of-change by fitting a least square regression to all shorelines at specific transects.

Calculations were made using $10 \mathrm{~m}$ spaced transects, generated perpendicular to a baseline, which was drawn approximately parallel to the coast. The results are represented as a graphic and plotted as a histogram. The coloured histogram represents two DSAS parameters simultaneously, allowing a fast perception of the coastline evolution over time. The bar length indicates how much the coastline has shifted during the analysis period (SCE parameter), and the bar colour indicates the NSM and the LRR, with the colour (green, yellow and red) being associated with the evolutionary trend of the coastline. The green scale designates the sectors in accretion and the yellow and red colour ones, the sector in erosion.
Combining both variables visually, the user can rapidly deduce that the coast has changed over time although presently it is in at the same or a similar position compared to what it was at the past and also determine how much it has changed, in absolute value.

For the peculiar coastal sector containing the barrier islands, the presence of the associated inlets brought some difficulties with DSAS data processing due to its migration over time and due to the curved coastline shape near the inlet spits. These curved lines were difficult to be processed by DSAS given the inevitable interception of different shoreline curves associated to the spit natural evolution. To bypass this problem and avoid producing data related to the localized effects of inlet-barrier tip morphological readjustments, the curved lines were removed for DSAS calculations. As a result, less historical shorelines were considered in these areas, and therefore, the analysed time period, depending on the number of curved lines removed, represents less than 65 years. Less historical coastlines also exist in places where inlets occurred in the past and are presently occupied by dunes.

The uncertainty calculation of the coastline position, for each year, was determined according to (Fletcher et al. 2003), where Uncertainty (U) is the result of the square root of the sum of the squares of the errors associated with the 3 parameters (Resolution of the aerial photo image $\left(\mathrm{E}_{\mathrm{ir}}\right)$, Image rectification $\left(\mathrm{E}_{\mathrm{r}}\right)$ and Digitization of the coastline $\left(\mathrm{E}_{\mathrm{d}}\right)$ :

$U=\sqrt{\left(\mathrm{E}_{\mathrm{d}}^{2}\right)+\left(\mathrm{E}_{\mathrm{r}}^{2}\right)+\left(\mathrm{E}_{\mathrm{ir}}^{2}\right)}$

The component associated with the coastline digitization $\left(E_{d}\right)$ procedure, for each year, was determined with DSAS using the two coastline lines marked by the two different operators for each analysed year. The image resolution, $\mathrm{E}_{\text {ir }} \mathrm{pa}-$ rameter, corresponds to the pixel resolution of the aerial photos and orthophotos. Given that for the rectification procedure, $\left(E_{r}\right.$ parameter), the Spline interpolation method, whose associated RMS (Root Mean Square) error is null, was used, the georeferencing error was estimated by using, at least, 35 control points randomly distributed across the mosaics of each flight. Thus, the rectification error $\left(\mathrm{E}_{\mathrm{r}}\right)$ was assumed to be the average value of the error measured at all control points, for each flight, as listed in Table 1 .

The uncertainty associated with the overall coastline evolution $\left(\mathrm{U}_{\mathrm{ce}}\right)$ during the time frame of 65 -years $(\mathrm{t})$, was determined using the uncertainty values $(\mathrm{U})$ calculated for each year according to (Fletcher et al. 2012):

$\mathrm{U}_{\mathrm{ce}}=\frac{\sqrt{\mathrm{U}_{\text {older }}^{2}+\mathrm{U}_{\text {recent }}^{2}}}{\mathrm{t}}$ 
Table 1 Uncertainty $(U)$ and Errors $\left(E_{d}, E_{i r}\right.$ and $\left.E_{r}\right)$ considered for DSAS calculations

\begin{tabular}{llllllll}
\hline Year & $\mathrm{E}_{\mathrm{d}}$ & $\mathrm{E}_{\mathrm{d}}{ }^{2}$ & $\mathrm{E}_{\mathrm{ir}}$ & $\mathrm{E}_{\mathrm{ir}}{ }^{2}$ & $\mathrm{E}_{\mathrm{r}}$ & $\mathrm{E}_{\mathrm{r}}{ }^{2}$ & $\mathrm{U}(\mathrm{m})$ \\
\hline 1950 & 2.18 & 4.75 & 0.24 & 0.06 & 2.1 & 4.41 & 3.04 \\
1958 & 2.17 & 4.71 & 0.3 & 0.09 & 3.66 & 13.40 & 4.27 \\
1972 & 5.01 & 25.10 & 0.27 & 0.07 & 1.81 & 3.28 & 5.33 \\
1980 & 1.16 & 1.35 & 0.34 & 0.12 & 2.02 & 4.08 & 2.35 \\
1985 & 3.41 & 11.63 & 0.36 & 0.13 & 1.97 & 3.88 & 3.95 \\
1991 & 5.13 & 26.32 & 0.43 & 0.18 & 1.65 & 2.72 & 5.41 \\
2005 & 1.4 & 1.96 & 0.5 & 0.25 & 5.4 & 29.16 & 5.60 \\
2010 & 1.26 & 1.59 & 0.5 & 0.25 & 1.28 & 1.64 & 1.86 \\
2015 & 0.83 & 0.69 & 0.5 & 0.25 & 0 & 0 & 0.97 \\
\hline
\end{tabular}

For this sector, the overall uncertainty $\left(\mathrm{U}_{\mathrm{ce}}\right)$ associated with the variation of the coastline along 65 years is $0.049 \mathrm{~m} /$ year.

\section{Results}

Historical coastlines, Shoreline Change Envelope (SCE), Coastal Linear Regression Rates (LRR) and Net Shoreline Movement (NSM) were determined and plotted between the São Luís Inlet (Ancão peninsula) and the Guadiana river, a $55 \mathrm{~km}$ long coastal sector.

As previously mentioned, the colour and the length of the bar displayed on both hazard maps (NSM map and LRR map) give information on two DSAS parameters simultaneously, allowing a fast perception of the past coastline evolution. Thus, the bar length indicates how much the coastline has shifted during the analysed 65 years (SCE), and the colour of the NSM and LRR bars, represents sectors in accretion (green scale) or sectors in erosion (yellow and red colour scale). The LRR map, represents the rate-of-change by fitting a least square regression to all shorelines at a specific transects (Fig. 2) whereas the NSM map indicates the absolute distance between the oldest (1950) and the youngest (2015) coastline position (Fig. 3). All the data is available as polylines with a $10 \mathrm{~m}$ spaced resolution and openly accessible at the LNEG GeoPortal [https://geoportal.lneg.pt $/ \mathrm{mapa} /$ ?escala= 4000000\&mapa=geologiacosteira\#], where it can be seen in a greater detail.

The global map outlook (Fig. 2) gives an evolutionary insight, with accretion at the western (Barreta island) and eastern (Cacela peninsula - Vila Real de Santo António) sectors, and a mostly erosional trend for the central barrier island system (Culatra, Armona, Tavira and Cabanas islands). The similar colour transitions between both DSAS parameters, NSM and LRR (Fig. 3), suggests a consistent evolution trend of the coastline at eastern Algarve between Barreta island and Vila Real de Santo António. With the exception of certain areas, the coastline tends to advance over time in one sector and retreats in another, not presenting cycles of progradation and retreat.

Maximum distances between the oldest and the most recent coastline positions (NSM), indicating a progradation in the order of $577 \mathrm{~m}$, are found at the eastern most sector, near the Vila Real de Santo António jetty, while maximum coastline retreat of $-235 \mathrm{~m}$ (NSM) is found at the Cabanas island (Fig. 3), with a LRR value of $-3.1 \mathrm{my}^{-1}$. The uncertainty of the rate of change for the analysed littoral fringe $\left(U_{\text {ce }}\right)$ is nearly $\pm 0.05 \mathrm{my}^{-1}$.

\section{Barreta island}

In 2015 the Barreta island had an extension of approximately $5.8 \mathrm{~km}$. When comparing to 1950 , it is noticeable the decrease in total length of the island, being shorter approximately $2 \mathrm{~km}$.

The analysis of the Barreta island coastlines shows a consistent accretion evolution during the 65 -year time frame, with an average coastline progradation of $168 \mathrm{~m}$. The minimum NSM, of $58 \mathrm{~m}$, lies approximately $1900 \mathrm{~m}$ westwards of Santa Maria Cape, and the maximum progradation, $365 \mathrm{~m}$, is found on the previously mentioned cape (Fig. 4). The maximum LRR is also found in the Santa Maria Cape, with a value of $5.8 \mathrm{my}^{-1}$ and the location of the minimum, $0.8 \mathrm{my}^{-1}$, is coincident with the lowest NSM value.

In the proximity of the Faro inlet jetty, the progradation was quite fast, with the 1972 aerial photo already showing the maximum progradation value (SCE of $250 \mathrm{~m}$ ). After 1972 the coastline presents some oscillation having receded in $2015,27 \mathrm{~m}$ (NSM of $223 \mathrm{~m}$ ) from its maximum. The progradation at the Santa Maria Cape, shows a more continuous pattern, during the analysed time-period. Although some coastline data is missing in that area, from 1950 to1972, from 1972 to 1991 and from 1991 to 2015, the progradation was approximately $110 \mathrm{~m}, 83 \mathrm{~m}$ and, $176 \mathrm{~m}$ respectively.

\section{Culatra island}

Culatra island, with an extension of approximately $7.45 \mathrm{~km}$, increased its length by approximately $2.76 \mathrm{~km}$ from 1950 to 2015, due to the accretion of recurved spits at the eastern end of the island.

The island exhibits severe erosion, with LRR values up to $2.9 \mathrm{my}^{-1}$, at the western end, between the Farol and Culatra beach areas, and with a maximum regression of $-163.6 \mathrm{~m}$ (NSM) from 1950 to 2015. Eastwards of Culatra beach, in the central part of the island, accretion prevails (NSM up to $67.8 \mathrm{~m}$ and LRR of $1.9 \mathrm{my}^{-1}$ ), although a small fringe of erosion (NSM up to $-31.2 \mathrm{~m}$ and LRR of $-3.1 \mathrm{my}^{-1}$ ) occurs close to the beginning of the easternmost spit (Fig. 5).

At the eastern end of the island, accretion of up to $92.7 \mathrm{~m}$ (NSM) and $9.2 \mathrm{my}^{-1}$ (LRR) was observed between 2005 and 2015 (Fig. 5). 


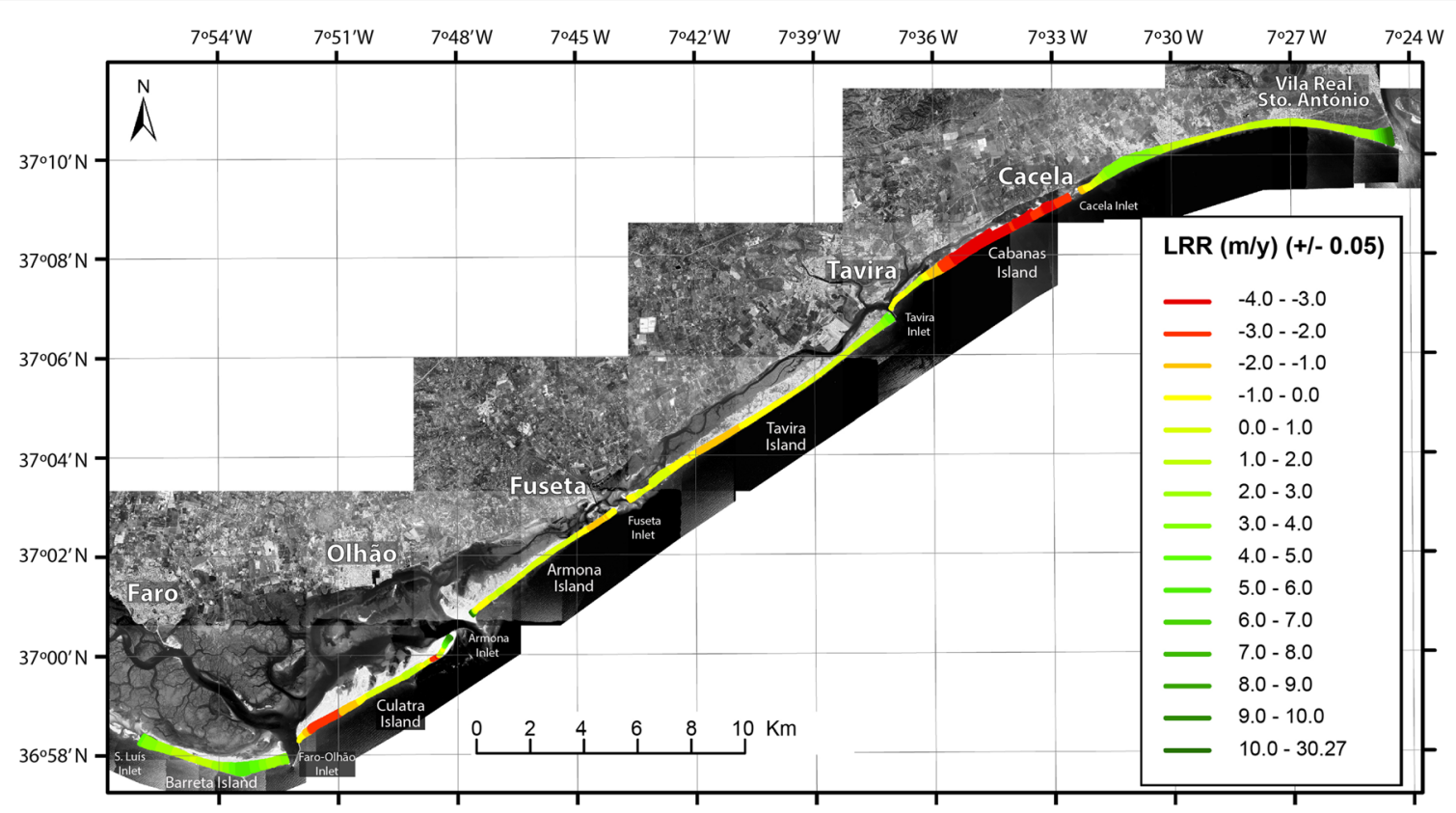

Fig. 2 Linear Regression Rates (LRR) for the analysed sector between Barreta island and Vila Real de Santo António. Background photo is the 2015 ortophoto. Map produced using ArcMap, a module from ArcGIS@ Desktop 10.6.1 of ArcGIS® software by Esri

\section{Armona island}

The Armona island, with an extension of approximately $7.2 \mathrm{~km}$, does not show significant changes in its coastline position in the central sector, during the analysed period (Fig. 6). However, from 1950 to 2015, its length has changed significantly. In 2015, it was approximately, $1700 \mathrm{~m}$ longer. From 1950 to 1991 the island grew continuously, reaching a maximum size of $9212 \mathrm{~m}$. An artificial new inlet was then opened, approximately $1900 \mathrm{~m}$ westward of the existing one, as can be seen in the 2010 aerial photo, creating a small island between the two. In 2015 the older inlet was already closed and the artificial one became the main inlet separating the Armona and Tavira islands. The island shows accretion along $3900 \mathrm{~m}$ and erosion along $3300 \mathrm{~m}$ with an average progradation and erosion (NSM) of $46 \mathrm{~m}$ and $-28 \mathrm{~m}$, respectively. Contrary to Culatra island, the westward end of the Armona island is in accretion (Fig. 6). In fact, the most

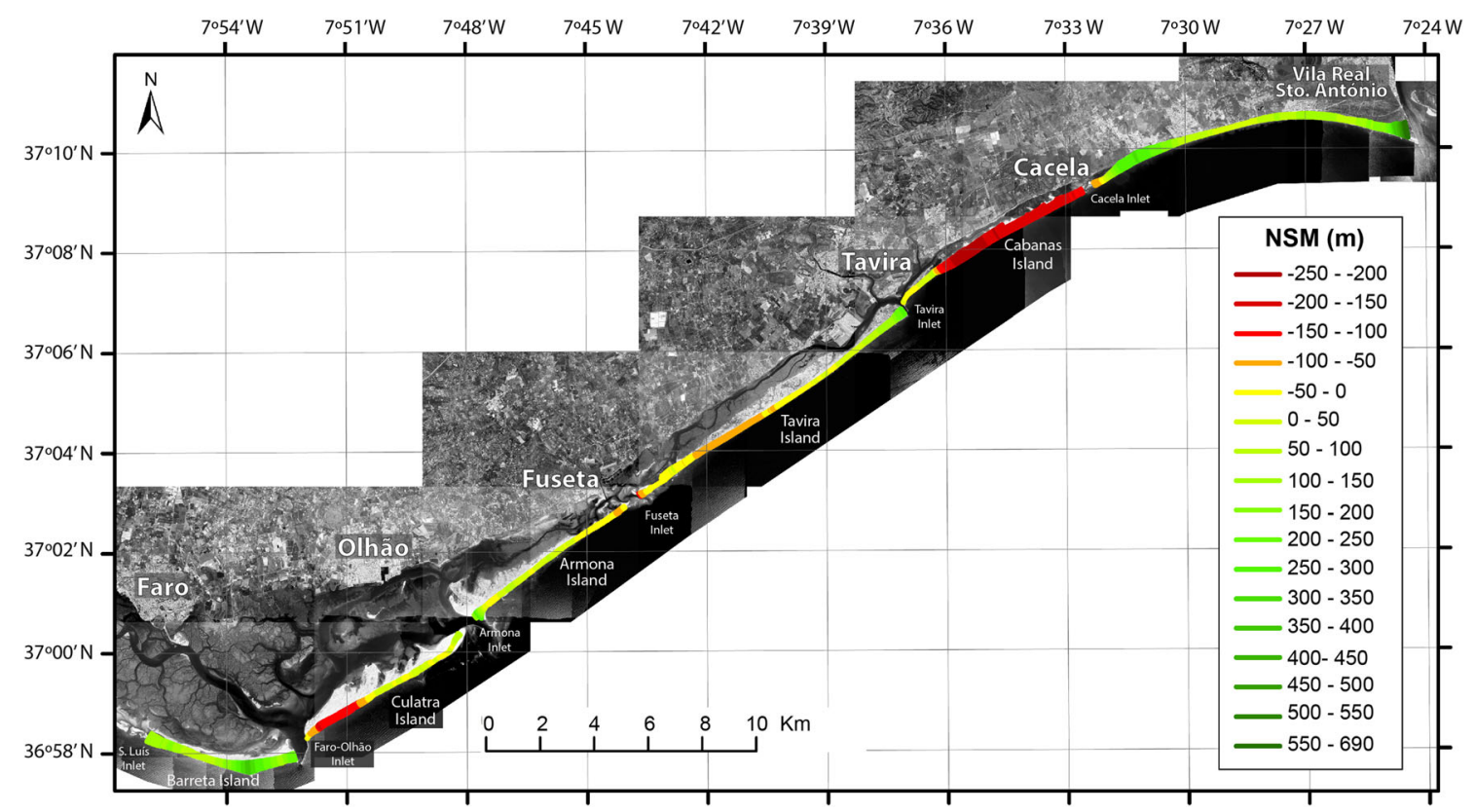

Fig. 3 Net Shoreline Movement (NSM) for the analysed sector between Barreta island and Vila Real de Santo António. Background photo is the 2015 ortophoto. Map produced using ArcMap, a module from ArcGIS@ Desktop 10.6.1 of ArcGIS® software by Esri 
Fig. 4 Historical coastline position, Linear Regression Rate (LRR) and Net Shoreline Movement (NSM) at Barreta island. Background photo is the 2015 ortophoto. Map produced using ArcMap, a module from ArcGIS@ Desktop 10.6.1 of ArcGIS® software by Esri
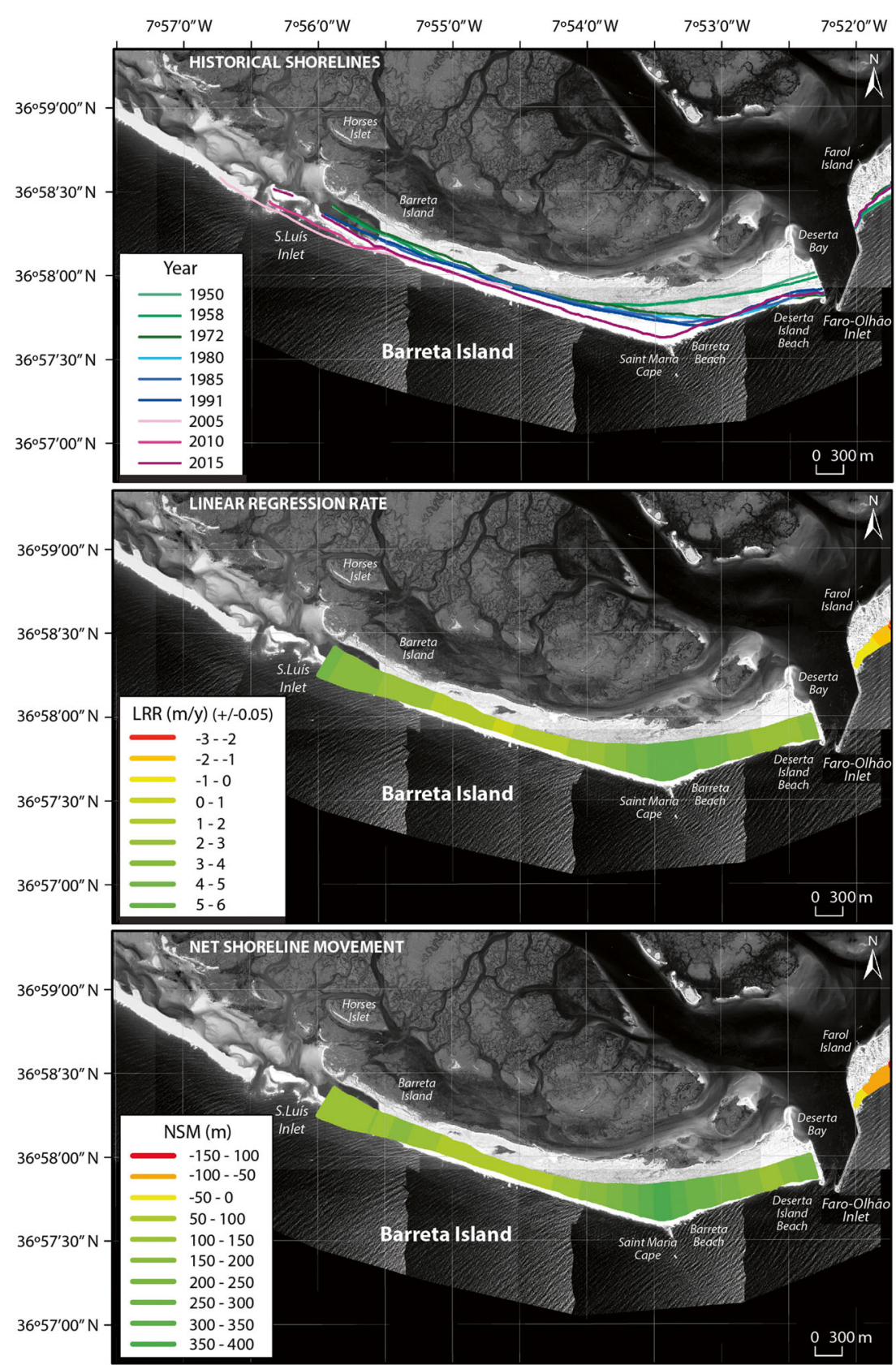

significant changes in coastline position occur associated with the Armona (at the west) and the Fuseta (at the east) inlet dynamics, with an accretion (NSM) up to $302 \mathrm{~m}$ (LRR up to $30 \mathrm{my}^{-1}$ ) near the Armona inlet and erosion (NSM) of $-82.8 \mathrm{~m}$ (LRR up to $-1.3 \mathrm{my}^{-1}$ ) near the Fuseta inlet (Fig. 6).

\section{Tavira island}

The Tavira island is the largest island of the barrier system, approximately $12,1 \mathrm{~km}$ long. It decreased its length nearly $1100 \mathrm{~m}$, from 1950 to 2015 , which is explained by the eastward migration of the Fuseta inlet. It presents a long-term tendency of erosion, with $8050 \mathrm{~m}$ of an eroding coastline, in the western part of the island, and $4050 \mathrm{~m}$ of accretion coastline, in the eastern part of the island. The maximum coastline displacement values, during the 65-year period of analyses, are located in both extremes, with accretion (NSM) going up to $251 \mathrm{~m}$, with a LRR of 4,7 $\mathrm{my}^{-1}$, near the Tavira jetty, and erosion reaching a NSM of $-116 \mathrm{~m}$, near the Fuseta inlet (Fig. 7).

Excluding the inlet area, the sector of the island with the highest erosion since 1950 is located near the Homem $\mathrm{Nu}$ beach (Fig. 7). This $3000 \mathrm{~m}$ coastal stretch shows a maximum retreat of $-92 \mathrm{~m}(\mathrm{NSM})$, with an erosion rate of $-1.5 \mathrm{my}^{-1}$ (LRR), and an average retreat of $-72 \mathrm{~m}$ (NSM), significantly higher than the average erosion of the $8050 \mathrm{~m}$ eroded coastal sector (NSM of $-46 \mathrm{~m}$ ). 
Fig. 5 Historical coastline position, Linear Regression Rate (LRR) and Net Shoreline Movement (NSM) at Culatra island. Background photo is the 2015 ortophoto. Map produced using ArcMap, a module from ArcGIS@ Desktop 10.6.1 of ArcGIS® software by Esri
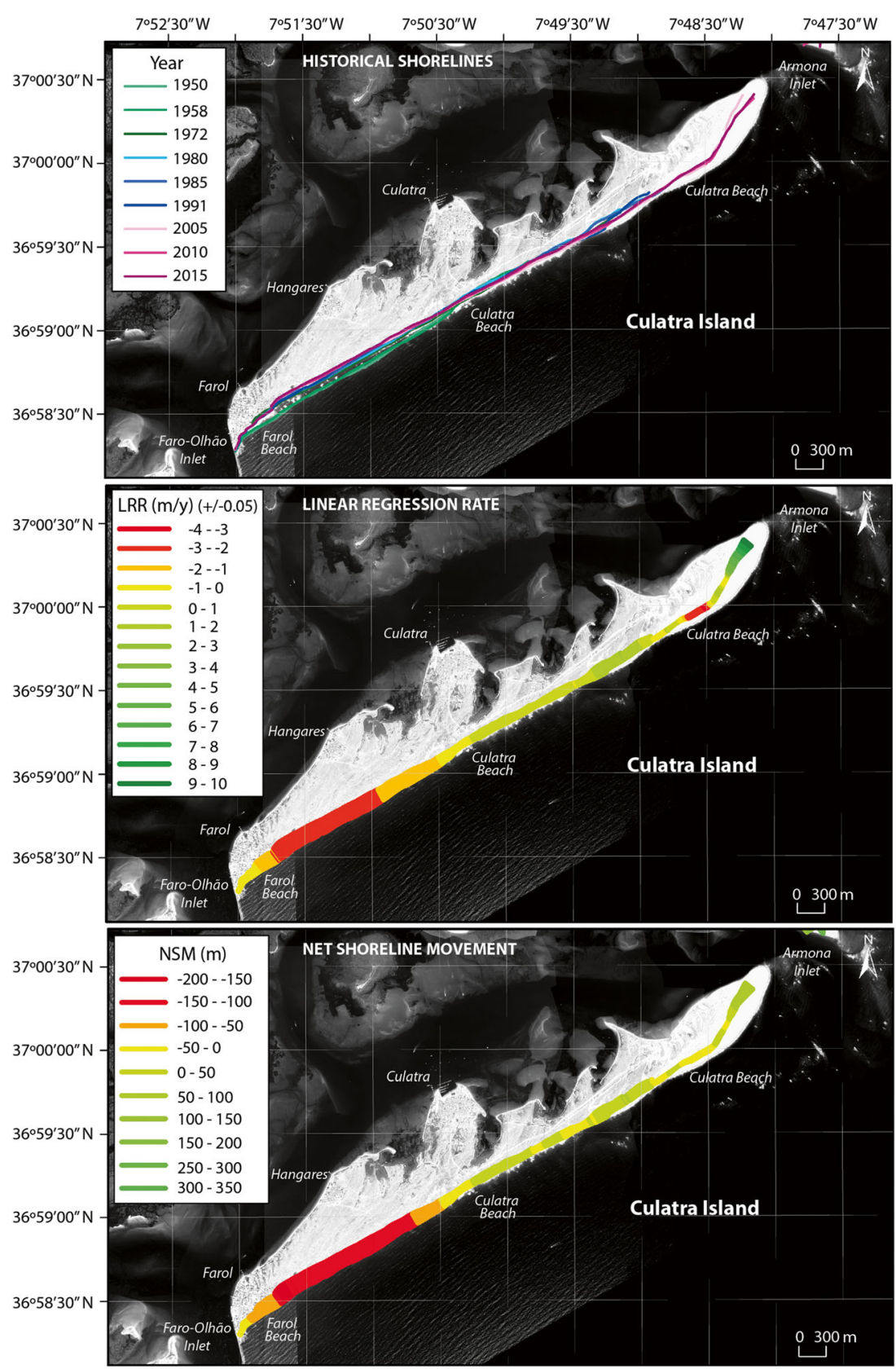

\section{Cabanas island}

Cabanas island has an approximately extension of $8,03 \mathrm{~km}$ and is the only coastal barrier of the system that started to form after 1958. In the aerial photos taken in 1950 and 1958, Cabanas island was still absent, appearing first in 1972 dataset (Electronic supplementary material: animated Gif). The growth is significant: in 1972 the island had a length of $2580 \mathrm{~m}$ long; in 1980, $3280 \mathrm{~m}$; in 1985, $5000 \mathrm{~m}$; in 1991, $5290 \mathrm{~m}$; in 2005, $6320 \mathrm{~m}$; in 2010, $6500 \mathrm{~m}$ and in 2015, $8030 \mathrm{~m}$. Taking these values into consideration, the average length of the longitudinal growth was higher than $140 \mathrm{my}^{-1}$.
Cabanas is, notoriously, the most displaced island of the barrier system, with three quarters of it suffering a retreat of the shoreline position of at least $100 \mathrm{~m}$ since 1950 (Fig. 8), comparing to the former, and eroded, coastal barrier. Contrary to the other islands that have a fixed landward position and variable seaward location, regardless if they are under erosion or accretion, the Cabanas island has a landward displacement in such a way that the inland limit in 1950 was approximately the current position of the modern seaward limit. That is to say, the landward displacement, from 1950 to 2015, caused a narrowing of the back-barrier channel in the same proportion (Fig. 9). The average value for the 2015 coastline position, in 
Fig. 6 Historical coastline position, Linear Regression Rate (LRR) and Net Shoreline Movement (NSM) at Armona island. Background photo is the 2015 ortophoto. Map produced using ArcMap, a module from ArcGIS@ Desktop 10.6.1 of ArcGIS@ software by Esri

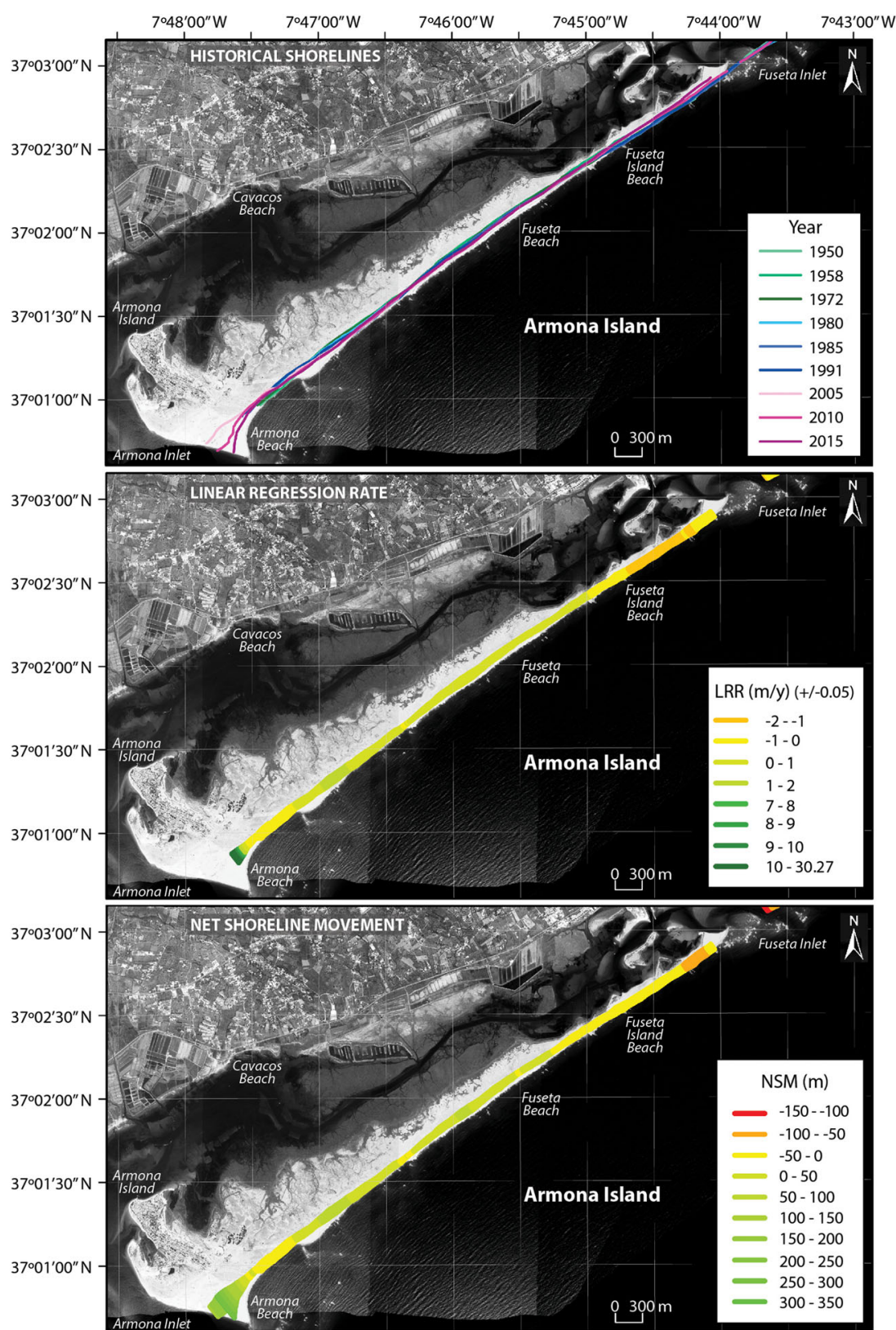

comparison with 1950 , is approximately $130 \mathrm{~m}$ onshore, with a maximum retreat of $-235 \mathrm{~m}$ (NSM values) at a $-3.8 \mathrm{my}^{-1}$ rate (LRR). This retreat value is the highest registered for the barrier island system during the analysed period.

The western end of the island, after the Tavira inlet, also shows erosion, albeit with lower values. There, a coastline retreat (average NSM of $-13 \mathrm{~m}$, with a maximum of $-36 \mathrm{~m}$ ) is observed along a $900 \mathrm{~m}$ coastal stretch, which is then followed by a $750 \mathrm{~m}$ sector with accretion.

\section{Cacela peninsula}

The Cacela peninsula is approximately $1270 \mathrm{~m}$ long and, as previously referred, has diminished significantly its length, as the Cabanas island grew eastward since 1950 to 2015 , namely from $7800 \mathrm{~m}$ to its present size.

The peninsula sector reveals two different behaviours in terms of coastline displacement: erosion on its western side, and changing gradually to accretion, on its eastern size (Fig. 10).

The first half, where erosion is dominant, shows an average retreat of $-49.6 \mathrm{~m}$ (NSM) with a maximum value of $-99.10 \mathrm{~m}$. The average rate of coastline displacement (LRR) is $-0.67 \mathrm{my}^{-1}$ with a maximum of $-1.18 \mathrm{my}^{-1}$ at its western end. Progradation occurs in the second half of the peninsula, with increasingly higher values to the west. The average progradation is $140.4 \mathrm{~m}$ (NSM) with a maximum value of $244.3 \mathrm{~m}$. The average rate of the coastline displacement 
Fig. 7 Historical coastline position, Linear Regression Rate (LRR) and Net Shoreline Movement (NSM) at Tavira island. Background photo is the 2015 ortophoto. Map produced using ArcMap, a module from ArcGIS@ Desktop 10.6.1 of ArcGIS® software by Esri
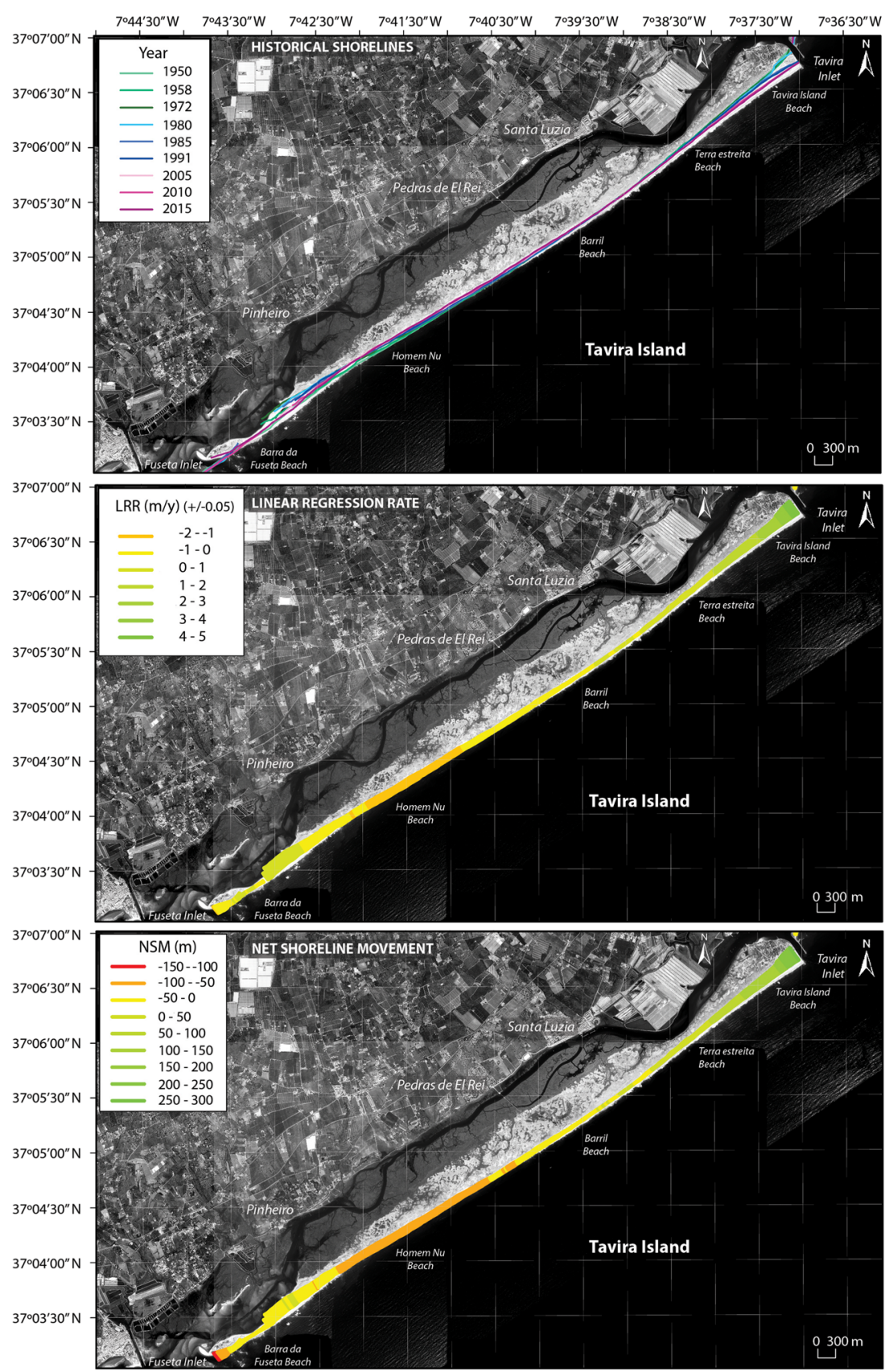

(NSM) is $1.37 \mathrm{my}^{-1}$, with a maximum of $2.72 \mathrm{my}^{-1}$ at its eastern end.

\section{Manta Rota - Vila Real de Santo António sector}

The average NSM for the entire sector is $136.8 \mathrm{~m}$, with a minimum value of $16.9 \mathrm{~m}$ and a maximum of $577 \mathrm{~m}$. The accretion rate (LRR) varies from $0.23 \mathrm{my}^{-1}$ to $11.5 \mathrm{my}^{-1}$, with an average of $2.06 \mathrm{my}^{-1}$. Considering the whole sector, this coastal fringe has gained an area of approximately $1,5 \times 10^{6} \mathrm{~m}^{2}$.
Although progradation occurs along the overall sector, coastline displacement varies significantly (Fig. 10). The NSM and LRR parameters, for the most known beaches in this sector, from west to east, are summarized in Table 2 .

\section{Erosion and accretion areas}

The NSM, by its definition, is a linear measure of the coastline displacement from the oldest dataset to the most recent dataset. Hence, the area due to the occurred changes can be calculated 
Fig. 8 Historical coastline position, Linear Regression Rate (LRR) and Net Shoreline Movement (NSM) at Cabanas island. Background photo is the 2015 ortophoto. Map produced using ArcMap, a module from ArcGIS@ Desktop 10.6.1 of ArcGIS® software by Esri

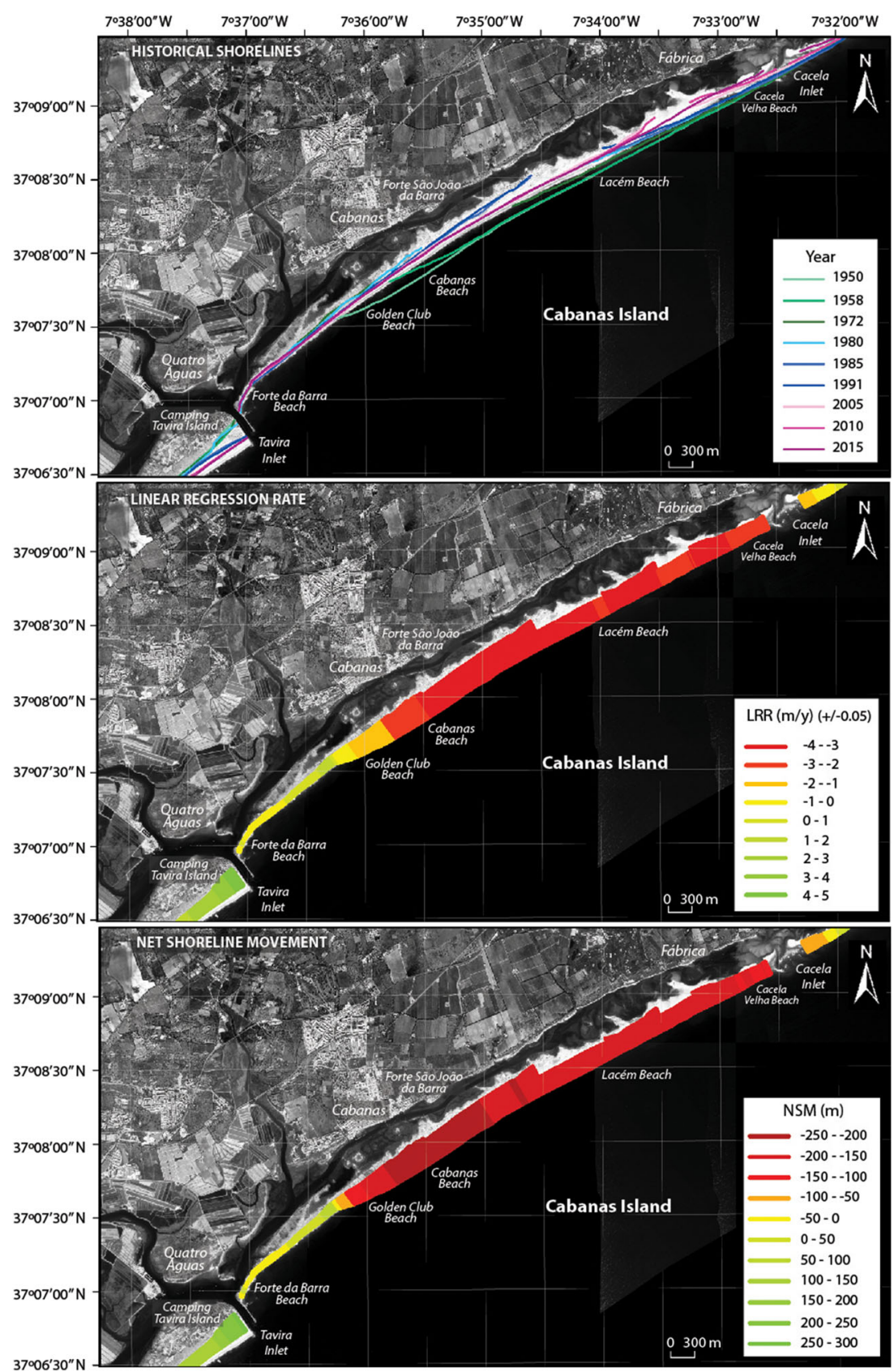

sectors have gained area (Barreta island, Armona island, Cacela peninsula and Manta Rota-VRSA) whereas others have lost (Culatra island, Tavira island and Cabanas island).
Fig. 9 Coastlines from 1950 and 2015. Former position of Cacela peninsula (light brown), significantly offshore in relation to the new Cabanas island (orange). Map produced using ArcMap, a module from ArcGIS@ Desktop 10.6.1 of ArcGIS® software by Esri

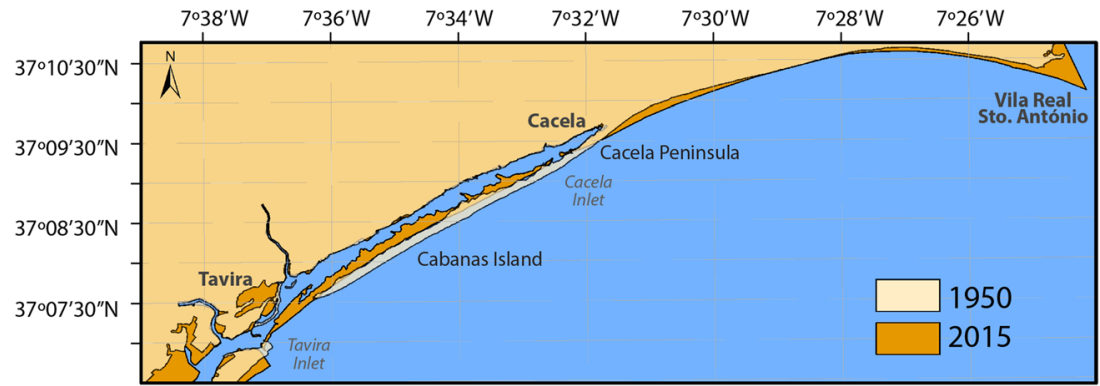


Fig. 10 Historical coastline position, Linear Regression Rate (LRR) and Net Shoreline

Movement (NSM) between Cacela peninsula and Vila Real de Santo António. Background photo is the 2015 ortophoto. Map produced using ArcMap, a module from ArcGIS@ Desktop 10.6.1 of ArcGIS® software by Esri
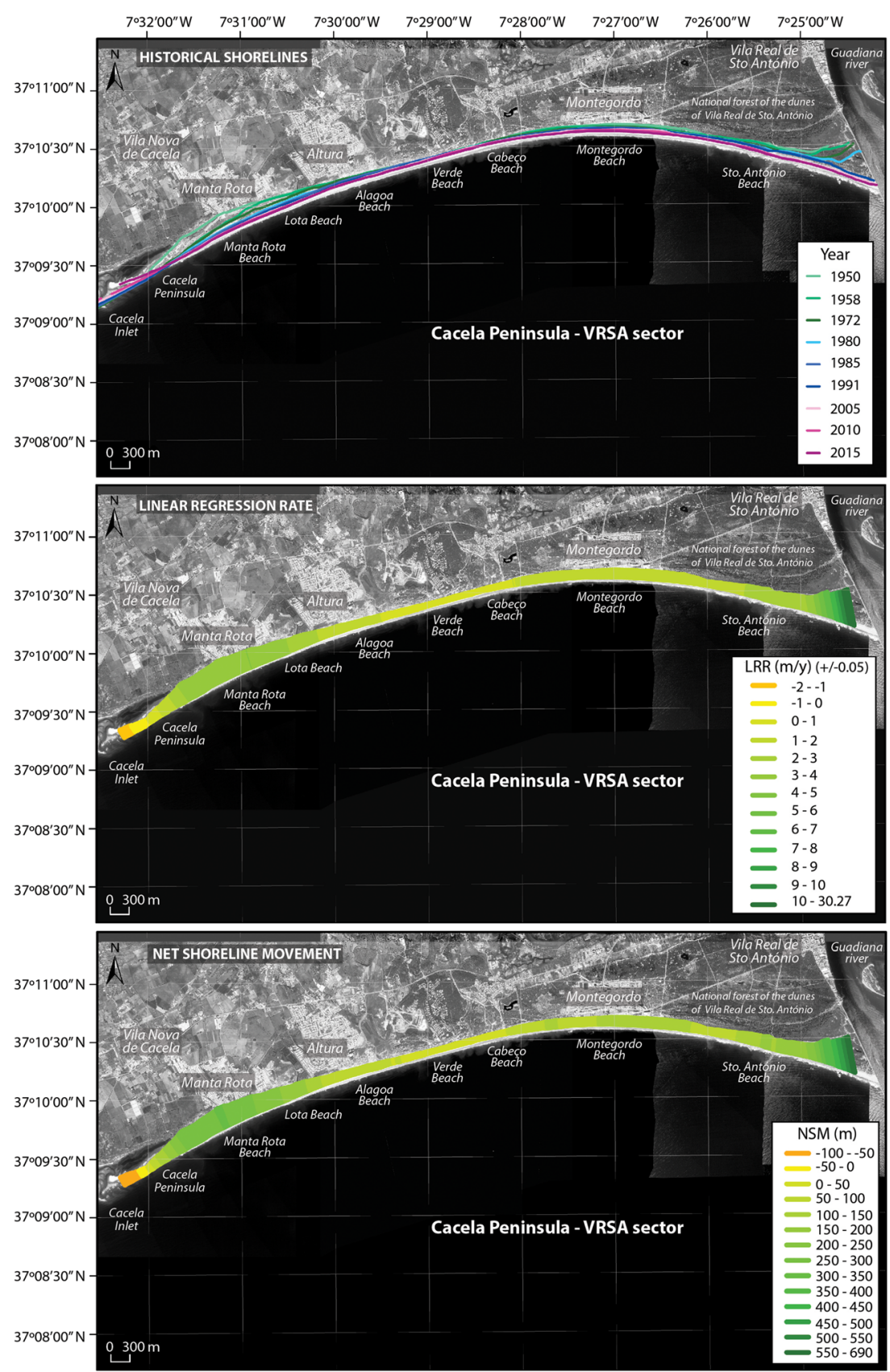

\section{NSM and SCE comparison}

The NSM and SCE comparison indicates that its difference is high in some areas and, on the contrary, it is quite negligible in others (Fig. 11 and Table 4). Whereas the Cacela peninsula Vila Real de Santo António sector shows similar NSM and SCE values, at the barrier islands, these parameters have differences that, in some areas, can go up to hundreds of meters (Fig. 11).

Table 2 - Average (*) NSM and LRR of a $100 \mathrm{~m}$ coastal sector (measured in front of the main access) of the most known beaches from Manta Rota to Vila Real de Santo António jetty (W-E)

\begin{tabular}{lllllllll}
\hline & Manta Rota beach & $\begin{array}{l}\text { Lota } \\
\text { beach }\end{array}$ & $\begin{array}{c}\text { Altura } \\
\text { beach }\end{array}$ & $\begin{array}{c}\text { Verde } \\
\text { beach }\end{array}$ & $\begin{array}{c}\text { Cabeço } \\
\text { beach }\end{array}$ & Monte Gordo beach & Santo António beach & VRSA jetty \\
\hline $\mathrm{NSM}^{*}(\mathrm{~m})$ & 302.7 & 218.0 & 77.8 & 23.3 & 31 & 106.2 & 149.2 & 533.8 \\
$\mathrm{LRR}^{*}\left(\mathrm{my}^{-1}\right)$ & 3.9 & 3.54 & 1.43 & 0.28 & 0.5 & 1.44 & 2.38 & 10.52 \\
\hline
\end{tabular}


Table 3 - Gained and lost areas $\left(\mathrm{m}^{2}\right)$, for each analysed sector

\begin{tabular}{llllllll}
\hline & Barreta island & Culatra island & Armona island & Tavira island & Cabanas island & Cacela peninsula & Manta Rota-VRSA sector \\
\hline Area $\left(\mathrm{m}^{2}\right)$ & 919,720 & $-262,110$ & 87,779 & $-105,101$ & $-1,118,219$ & 53,537 & $1,477,975$ \\
\hline
\end{tabular}

\section{Discussion}

\section{Long-term Portuguese south-eastern coastline evolution (1950-2015)}

The discussion of the coastline evolution on this littoral fringe is somewhat complex as a great part of it includes the Ria Formosa barrier islands and the coastal lagoon system. These respond to various drivers, in a short to medium term (tide processes, wave energy, water level changes during storms) or a longer term (sea-level change, storminess patterns) (Cooper et al. 2018). Moreover, the island evolution depends on many processes such as the shoreline retreat, longshore drift, overwash, dune building, tidal delta incorporation, inlet- associated processes and with a negligible effect on the Ria Formosa barrier islands system, the erosion of back-barrier regions of the islands by spring tides (Pilkey et al. 1989). In addition to the intricacy inherent to this peculiar system, human activities disturbed its natural dynamics inducing relevant changes on coastal behavior during the last decades, increasing processes complexity and challenging, even more, the already demanding understanding of coastal evolution (Ferreira et al. 2016).

Regarding the overall coastline movement from 1950 to 2015 , seaward displacement prevails, with a prograding coastline occupying approximately $54 \%$ of the studied sector. As perceived from the dataset obtained from the 65-years period, the coastline evolution from São Luís inlet (at Ancão peninsula) to the Vila Real de Santo António jetty is characterized by a seaward progradation tendency in the western (Barreta island) and eastern sectors (Cacela peninsula - Vila Real de Santo António) and an erosional trend at the central part of the barrier island system. However, the islands coastline does not evolve evenly and, occasionally, it evolves in the same direction as a result of the local (artificial) processes, that overlap the general natural trend and may strongly contribute to specific morphological local changes. Compared to recent published data for this area, the trend is similar to the one obtained at a national scale ( Lira et al. 2016), even though the values of the rate of change might differ in some sectors, which is likely explained by the longer time frame of analysis ( 65 years) and increased resolution (10 $\mathrm{m}$ space) used in this work.

Given that the coastlines from the sectors associated to the inlet spits, for each year, were previously removed, the current set of data does not contain outliers derived from those short-term positions, thus reducing their localized effects. Inlet displacement also introduces some particularities in the analysis, causing a local reduction in the number of coastlines used and, in some cases, diminishing the time-period of the analysis. Although the discontinuous erosion/accretion pattern observed along the islands, is inherent to the dynamics of the natural long-term barrier island evolution, human interaction has also to be taken into account since artificial replenishments (promoting an increment on sand supply) and groin constructions, mainly for fixing the inlets position, (promoting accretion on the up-drift and erosion on the down drift side) have a strong impact on coastline evolution.

Besides the erosion/accretion pattern associated with the inlet related processes, in a general and simple long-term approach, the natural seaward erosional tendency of the barrier islands, and its onshore migration behaviour, could be associated to the sea-level rise (Pilkey et al. 1989) or, alternatively, to a restricted sand supply (Niedoroda et al. 1985). Over the 65 -year time period, the estimated sea-level rise of approximately $9.75 \mathrm{~cm}$ (based on $1.5 \pm 0.2 \mathrm{mmy}^{-1}$, from Dias and Taborda 1992) would not inhibit the aggradation and landward widening of the barrier islands resulting from fresh overwash sand and eolian deposition, when sediment supply
Table 4 Averages of NSM values (*absolute value), SCE values, and $\%$ of $\mathrm{NSM}^{*}$ that is equivalent to SCE for each barrier island and for the Cacela peninsula - Vila Real de Santo António sector

\begin{tabular}{llll}
\hline Sector & Average NSM* $(\mathrm{m})$ & Average SCE $(\mathrm{m})$ & NSM/SCE $\times 100$ \\
\hline Barreta island & 167.5 & 208.8 & 80.2 \\
Culatra island & 58.1 & 76.3 & 76.1 \\
Armona island & 37.6 & 53.7 & 70.0 \\
Tavira island & 50.9 & 73.1 & 69.6 \\
Cabanas island & 148.3 & 193.8 & 76.5 \\
Cacela peninsula - VRSA & 133.6 & 138.1 & 96,7 \\
\hline
\end{tabular}


from littoral drift is available (Woodroffe and D 2002). This necessary sediment supply may be partially explained by the artificial nourishments of approximately $819,000 \mathrm{~m}^{3}$, made between 2011 and 2017, in the beaches to the west of the study area, namely in the region of Albufeira, but also by the artificial beach and dune nourishments made inside the study area (Table 5).

Significant seaward shoreline progradation at the western (Barreta island), but particularly in the Manta Rota - Vila Real de Santo António sector, showing a clear positive sediment budget, in contrast with the referred coastal erosion and onshore island migration, suggests sediment availability in the littoral drift which raises interesting questions in relation to the overall system's adaptation over time. Moreover, the recurrent and severe silting of the channels of Ria Formosa, associated with the sediment infill due to inlet dynamics, also suggests availability of sediments sourced from the littoral drift.

\section{Barreta island}

The Barreta island experienced an important seaward progradation trend during the 65 -year period, with linear regression rates varying between approximately 1 and 6 $\mathrm{my}^{-1}$ and achieving its highest values at the Santa Maria Cape (Fig. 4), likely explained by the availability of sediment from up-drift sedimentary sources derived from the cliffs erosion between the Falésia beach and Garrão (Teixeira 2009). Moreover, additional sediment may also derive from the erosion of the recurrent artificial nourishments made in the Ancão peninsula.
The stability of the coastline position since the 1970's decades, eastwards of Santa Maria Cape, may be explained by the fulfilment of the maximum limit of sedimentary accumulation conditioned by the Faro-Olhão inlet's jetty. On the other hand, near the Santa Maria Cape, the maximum coastline displacement was only reached in 2015 , the different coastline shape being notorious. This may be a consequence of underwater sand accumulation related to the dynamics of the new artificial Faro inlet. Barreta island also suffered significant changes in its length, diminishing from 7.8 to $5.8 \mathrm{~km}$. This difference is mostly explained by the Ancão inlet position migration, at the western most part of the island (an unvegetated low-elevation and narrow $1565 \mathrm{~m}$ strip of sand), and erosion due to the Faro inlet, at the eastern tip of the island (500 m).

\section{Culatra island}

Besides natural processes, Culatra island is highly influenced by anthropogenic causes, namely the Faro-Olhão inlet construction, which explains the severe down-drift erosion of $2.9 \mathrm{my}^{-1}$ and a shoreline retreat of $163.6 \mathrm{~m}$ at the Farol beach area (Fig. 5). This problem was initially mitigated by a seawall and a groin construction, and more recently by two artificial sand supply operations performed in 2015 , one with 350,000 $\mathrm{m}^{3}$ and another with $150,000 \mathrm{~m}^{3}$ (Table 5). In opposition, accretion of about $92 \mathrm{~m}(\mathrm{NSM})$ and a progradation rate of $9.2 \mathrm{my}^{-1}$ (LRR) were observed, between 2005 and 2015, at the eastern end of the island, associated with sand deposition in the form of spits, related to the natural eastward migration of the Armona inlet. Indeed, and particularly in this island,
Fig. 11 NSM (*absolute value) and SCE for each barrier island and for Cacela peninsula - Vila Real de Santo António sector. Y axis: transect position; $\mathrm{X}$ axis: shoreline movement $(\mathrm{m})$ for each analysed sector

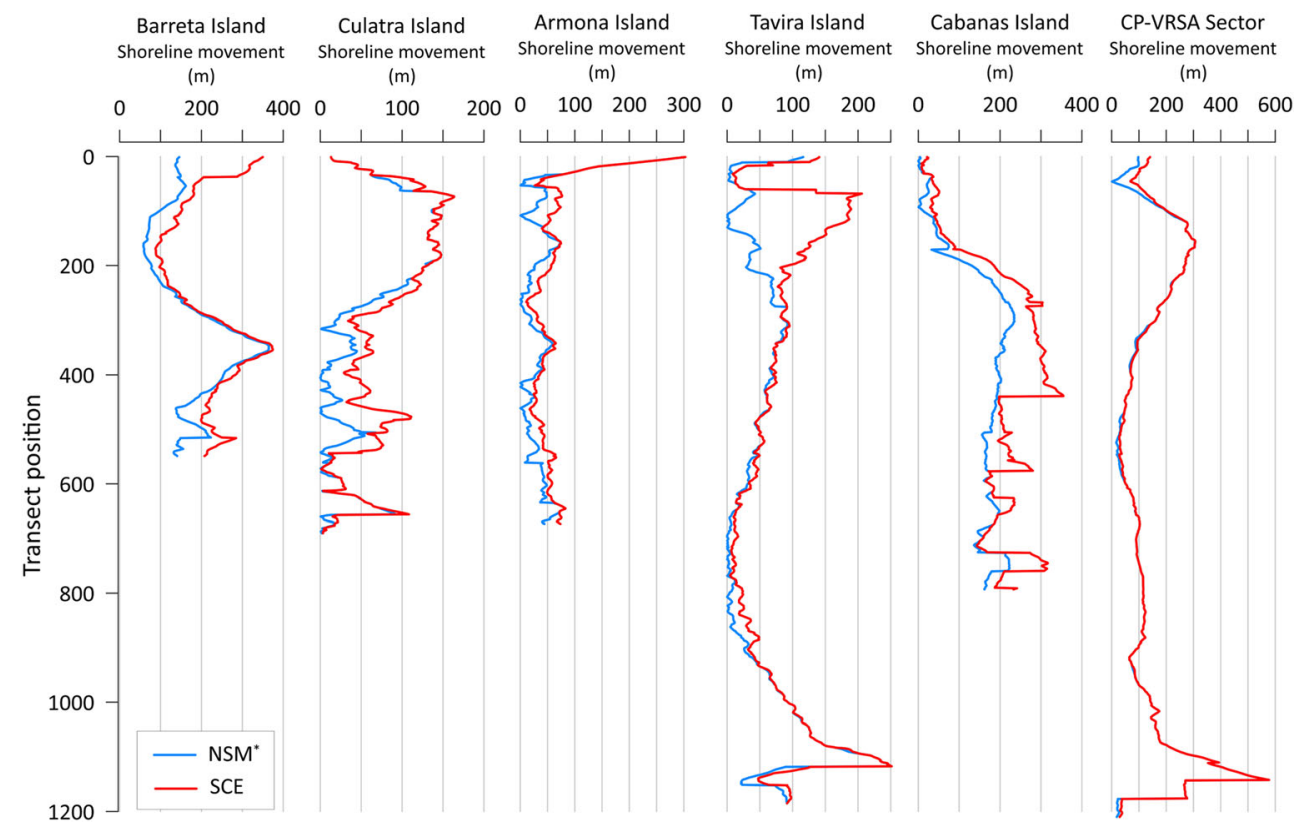


Table 5 Artificial sand deposition carried out in the south eastern sector of Portugal, between 1950 and 2017 and listed from west to east. Data from (Pinto et al. 2018)

\begin{tabular}{|c|c|c|c|c|c|c|c|}
\hline Location & County & Date & $\begin{array}{l}\text { Volume } \\
\left(\mathrm{m}^{3}\right)\end{array}$ & Deposition type & Loan spot & Device & Objective \\
\hline \multirow[t]{2}{*}{ Farol Beach } & \multirow[t]{2}{*}{ Faro } & 2015 & 350,000 & emerged beach & $\begin{array}{l}\text { Maintenance dredging of } \\
\text { the Faro-Olhão inlet and } \\
\text { navigation channels of } \\
\text { the Faro harbour }\end{array}$ & Dredge & $\begin{array}{l}\text { Enhancement of the coastline stability } \\
\text { conditions }\end{array}$ \\
\hline & & 2015 & 150,000 & emerged beach & $\begin{array}{l}\text { Maintenance dredging of } \\
\text { Armona inlet navigation } \\
\text { channel }\end{array}$ & Dredge & $\begin{array}{l}\text { Enhancement of the coastline stability } \\
\text { conditions }\end{array}$ \\
\hline Armona beach & Olhão & 2000 & 510,000 & $\begin{array}{l}\text { emerged beach } \\
\text { and dune }\end{array}$ & $\begin{array}{l}\text { Maintenance dredging - } \\
\text { Ria Formosa channels }\end{array}$ & Dredge & $\begin{array}{l}\text { Reduction vulnerability to overwash / } \\
\text { flooding }\end{array}$ \\
\hline \multirow[t]{3}{*}{ Tavira Beach } & \multirow[t]{3}{*}{ Tavira } & 1999 & 130,000 & $\begin{array}{l}\text { emerged beach } \\
\text { and dune }\end{array}$ & $\begin{array}{l}\text { Maintenance dredging - } \\
\text { Ria Formosa channels }\end{array}$ & Dredge & $\begin{array}{l}\text { Reduction vulnerability to overwash / } \\
\text { flooding }\end{array}$ \\
\hline & & 2003 & 9400 & emerged beach & $\begin{array}{l}\text { Dredging of the docking } \\
\text { basin - Tavira island } \\
\text { quay }\end{array}$ & Dredge & $\begin{array}{l}\text { Enhancement of the coastline stability } \\
\text { conditions }\end{array}$ \\
\hline & & 2004 & 4400 & emerged beach & $\begin{array}{l}\text { Dredging of the docking } \\
\text { basin - Tavira island } \\
\text { quay }\end{array}$ & Dredge & $\begin{array}{l}\text { Enhancement of the coastline stability } \\
\text { conditions }\end{array}$ \\
\hline \multirow[t]{3}{*}{ Cabanas Beach } & \multirow[t]{3}{*}{ Tavira } & 1999 & 380,000 & $\begin{array}{l}\text { emerged beach } \\
\text { and dune }\end{array}$ & $\begin{array}{l}\text { Maintenance dredging - } \\
\text { Ria Formosa channels }\end{array}$ & Dredge & $\begin{array}{l}\text { Reduction vulnerability to overwash/ } \\
\text { flooding }\end{array}$ \\
\hline & & 2002 & 700 & emerged beach & $\begin{array}{l}\text { Maintenance dredging - } \\
\text { Ria Formosa channels }\end{array}$ & Truck & $\begin{array}{l}\text { Reduction vulnerability to overwash / } \\
\text { flooding }\end{array}$ \\
\hline & & 2005 & 8000 & emerged beach & $\begin{array}{l}\text { Cabanas navigation } \\
\text { channel }\end{array}$ & Dredge & $\begin{array}{l}\text { Enhancement of the coastline stability } \\
\text { conditions }\end{array}$ \\
\hline $\begin{array}{l}\text { Cabanas Beach } \\
\text { (island) }\end{array}$ & Tavira & 2014 & 50,000 & $\begin{array}{l}\text { emerged beach } \\
\text { and dune }\end{array}$ & $\begin{array}{l}\text { Dredging of the ebb delta } \\
\text { from Tavira inlet }\end{array}$ & Dredge & $\begin{array}{l}\text { Reduction vulnerability to overwash/ } \\
\text { flooding }\end{array}$ \\
\hline $\begin{array}{l}\text { Cabanas Beach } \\
\text { (west) }\end{array}$ & Tavira & 2016 & 175,000 & $\begin{array}{l}\text { emerged beach } \\
\text { and dune }\end{array}$ & $\begin{array}{l}\text { Maintenance dredging - } \\
\text { Ria Formosa channels }\end{array}$ & Dredge & $\begin{array}{l}\text { Enhancement of the coastline stability } \\
\text { conditions; Reduction vulnerability to } \\
\text { overwash / flooding }\end{array}$ \\
\hline Lacém Beach & $\begin{array}{l}\text { Vila Real de } \\
\text { Santo } \\
\text { António }\end{array}$ & 1997 & 480,000 & $\begin{array}{l}\text { emerged beach } \\
\text { and dune }\end{array}$ & $\begin{array}{l}\text { Maintenance dredging - } \\
\text { Ria Formosa channels }\end{array}$ & Dredge & $\begin{array}{l}\text { Enhancement of the coastline stability } \\
\text { conditions; Reduction vulnerability to } \\
\text { overwash / flooding; Protection of nat- } \\
\text { ural / cultural resources }\end{array}$ \\
\hline Cacela Beach & $\begin{array}{l}\text { Vila Real de } \\
\text { Santo } \\
\text { António }\end{array}$ & 2000 & 290,000 & $\begin{array}{l}\text { emerged beach } \\
\text { and dune }\end{array}$ & $\begin{array}{l}\text { Maintenance dredging - } \\
\text { Ria Formosa channels }\end{array}$ & Dredge & $\begin{array}{l}\text { Reduction vulnerability to overwash / } \\
\text { flooding }\end{array}$ \\
\hline
\end{tabular}

significant portions of the eastwards end of the islands owe their existence, and much of their sand volume, to inlet migration and channel filling processes (Pilkey et al. 1989). This reinforces the idea that lateral processes related to the longshore current system play a major role on the Culatra island lengthening and explains the approximately $2760 \mathrm{~m}$ increase in size from 1950 to 2015.

\section{Armona island}

The Armona inlet flow decrease and its larger subordination in relation to the new Faro inlet may have played an important role in the significant eastward growth of the island. Recent inlet silting and ebb-delta sand banks formation are in accordance with this hypothesis. The Armona island presents different evolutionary patterns in the west, central and eastern sectors. As mentioned, the western tip is strongly conditioned by the Armona inlet. As a consequence of the ebb-tidal delta growth, the island is growing from east to west and the beach is prograding with a coastline displacement reaching $302.6 \mathrm{~m}$ (LRR of up to $30.3 \mathrm{my}^{-1}$ ). Although natural, this process caused a down-drift erosion (eastwards), as shown in Fig. 6, probably due to changes in coastline orientation and local underwater morphology. In the central part of the island, an overall positive sand budget exists, reflecting on a seaward displacement of the coastline: throughout the $3500 \mathrm{~m}$ long central sector, a maximum NSM of $74 \mathrm{~m}$ and a minimum of $-4.4 \mathrm{~m}$ are observed, with an average progradation of $28 \mathrm{~m}$. The eastern tip of the island, westward of the Fuseta inlet, shows a significant coastal retreat (Fig. 6). This erosion is 
related to the instability of that particular area, which corresponds to a fast-growing sector, throughout the period of study, due to spit incorporation. Indeed, from 1950 to 1991, a 56-year period, the inlet shifted $3150 \mathrm{~m}$ eastward, at a rate of approximately $75 \mathrm{my}^{-1}$. In 2015, a new inlet existed, based on an artificial overture made around 2010, but which already showed an eastward migration tendency (380 m from 2010 to 2015). Artificial replenishment has recently been carried out to mitigate the coastal retreat and overwash events in this low-lying island stretch. A $510,000 \mathrm{~m}^{3}$, volume of sediment was deployed in 2000, as shown in Table 5, contributing to minimize erosion impacts and to increment littoral drift availability, enhancing the stability conditions of the coastline position, although complicating the analysis of the natural evolution of the system.

\section{Tavira island}

The Tavira island presents a long-term trend of erosion, except at its eastern end, where accretion occurs. In the first $8700 \mathrm{~m}$, where erosion prevails with an average retreat (NSM) of $-41.6 \mathrm{~m}$, the maximum retreat is associated with the Fuseta inlet influence (NSM of $-116 \mathrm{~m}$ ). In order to compensate the longshore sediment drift losses, due to the Fuseta inlet sediment retention, and to mitigate coastal erosion, which was promoting the foredune breaching and overwash events, artificial nourishment of Barril beach was carried out (Table 5). At Barril beach, but most importantly in the coastal sector to the west of this beach, erosion is particularly impacting since the foredune is low and narrow and the backdune environment corresponds to overwash sediments.

The last $3100 \mathrm{~m}$ of the island (its eastern end) shows an accretion trend, with higher values as it approaches the Tavira inlet. This progradation behaviour, in contrast with the erosion behaviour in the majority of the island, reaching a maximum NSM of $251 \mathrm{~m}$, is explained by the accumulation of sand, sourced by the longshore drift, against the western Tavira jetty.

\section{Cabanas island}

The actual Cabanas island is, as previously mentioned, a very recent island. As historical aerial photos show, in 1950 and 1958 the first $1700 \mathrm{~m}$ of Cabanas island (from west to east) were occupied by the ancient Tavira inlet, and, since then the island has grown progressively from west to east. The actual island is, in fact, very recent, therefore, the calculation of the coastline displacement in the current Cabanas island sector compares the new island coastline with the coastline of the old Cacela peninsula, which was progressively eroded by the inlet migration and gradually substituted by the newly formed Cabanas island.
As mentioned by Teixeira (2009), evidences of erosion are reported for the coastal stretch presently occupied by the island (formerly the western tip of the Cacela peninsula) prior to its existence, namely in the 1941 cyclone and later in the 1961 violent storm. Both these events caused a series of modifications in the barrier island system.

Besides the eventual natural retreat tendency, the island damage was likely intensified by the artificial opening of the Tavira inlet. The forced artificial relocation of the Tavira inlet and the construction of its jetties, played an important role in the down-drift sediment supply and in the anchoring point of the new Cabanas island. Aerial photo analysis shows a displacement of the Tavira inlet towards the east after 1958. As the inlet shifted eastwards and became wider, a new island started to form anchored in the new Tavira inlet jetty (presently the western tip of the island), which created the new Cabanas island. In 1972 the inlet was close to Cabanas and the island was already $2.5 \mathrm{~km}$ long. In 1980 the island was $3.2 \mathrm{~km}$ and continued to increase its length until 2015. As the new island got longer, the old Cacela peninsula was eroded due to the inlet migration. As a result, the inlet shift swept away the old Cacela peninsula and the new island occupies its place, but in a more onshore position. As the inlet shifted its position, it acquired different designations: Tavira, Cabanas, Lacém, Fábrica and more recently, Cacela inlet. At light of these facts, it is evident this island is the one that shows the most significant changes from 1950 to 2015. Its evolution became more difficult to interpret because of the human intervention tendency to go against the natural coastal evolution, with beach and dune renourishment and the opening of artificial inlets, in order to manage coastal erosion and lagoon silting (Table 5).

According to Cooper et al. 2018, in longshore driftdominated barriers a continued sediment supply is necessary to sustain barrier integrity, as evidenced by the dramatic effects of groin and jetty construction on down-drift systems. This seems to apply to the Tavira inlet jetties and Cabanas island recent evolution. The severe retreat trend has been marginally mitigated by several artificial sand supply operations that started in 1999 with $380,000 \mathrm{~m}^{3}$, followed by operations in 2002 with $700 \mathrm{~m}^{3}$ and an additional $8000 \mathrm{~m}^{3}$, in 2005 , with placement of palisades for dune buildings, in 2014 with $50,000 \mathrm{~m}^{3}$ and in 2016 with 175,000 $\mathrm{m}^{3}$ (Table 5). Erosion has also occurred in the western part of the island, near the Tavira inlet. Two groins where then built to control coastline retreat, however, as they didn't solve the erosion problem, and island breaching was likely to occur, artificial re-nourishment was deployed in $1999\left(130,000 \mathrm{~m}^{3}\right), 2003\left(9400 \mathrm{~m}^{3}\right)$ and $2004\left(4400 \mathrm{~m}^{3}\right)$ (Table 5). On the eastern part of the island, an artificial dune was built in $1997\left(480,000 \mathrm{~m}^{3}\right)$ and another one in $2000\left(290,000 \mathrm{~m}^{3}\right)$, from Lacém to Cacela, to enhance the conditions for coastline stability, reduce the vulnerability to overwash and flooding and to protect natural and cultural resources (Table 5). 
As it can be seen in the historical shorelines, plotted in Fig. 8 , artificial sand supply may have contributed to diminish the severe erosion tendency, evidenced by the seaward progradation of the coastline at Cabanas beach from the 1990 's to 2015. Although difficult to quantify, this action enhanced the stability of the coastline position. Otherwise, erosion rates would have been even greater.

\section{Cacela peninsula}

The actual Cacela peninsula is the remnant of a much larger sand barrier that had a reduction of its length due to the eastward shift of the Tavira inlet and growth of the Cabanas island. Taking into account the 65-year period of analysis, erosion occurred mainly in the western side of the peninsula. This retreat is progressively attenuated along the peninsula (Rebêlo and Nave 2018) as we move eastward, shifting to a strong accretion nearby Manta Rota beach. Old spits and dune crest analysis indicate that the first half of the peninsula, where erosion occurs, is related to the coastal barrier formed prior or during the Manta Rota inlet closure whereas the second half, where accretion occurs, is related with the fast prograding coast formed after the inlet closure. Thereby, the result may be seen as the reorientation of the coastline due to the Manta Rota inlet closure (that occurred during the first half of the last century) coupled with the eastward migration of the Cabanas (presently, Cacela) inlet.

At its eastern end, a maximum NSM of $244.7 \mathrm{~m}$ was measured. However, a wide beach already existed in 1950, but, since vegetated dunes were not visible in the aerial photos and due to the used coastline criteria, the progradation was assumed as post 1950, thus overestimating the post 1950 progradation values. This is a peculiar situation where the used criteria induced an error in coastal evolution.

The SCE and NSM data comparison (Fig. 12) allows us to conclude that recent erosion has a wider spatial expression than the overall analysis shows. Although only half of the sector seems to be affected by erosion in Fig. 10 (and that is the case if we compare the oldest and the most recent coastlines), recent coastline retreat, due to the inlet overture near Cacela, is already reaching the western limit of the sector. On the western part of the prograding coast, the coastline has already been 70-80 m offshore (Fig. 12), meaning that recent erosion has already shifted the coastline inland significantly. This recent erosion diminishes as we move east (Fig. 12).

\section{Manta Rota to Vila Real de Santo António jetty sector}

The sector from Manta Rota to VRSA jetty, as displayed by Figs. 2 and 10, shows an overall accretion trend during the 65year time period, the highest values being observed near Manta Rota and near the VRSA jetty. Manta Rota shows a notorious maximum of $306 \mathrm{~m}$ (NSM) progradation, with accretion rates (LRR) of up to $4 \mathrm{my}^{-1}$, considering the dune base as the coastline indicator. However, similar to what happened with the Cacela peninsula, a wide beach already existed in 1950 and, due to the coastline criteria used at this study, this wide beach was assumed as post 1950 progradation, thus overestimating the post 1950 NSM values here presented.

As shown in Fig. 10 and Table 2, coastline progradation varies significantly along the costal stretch. The sector from Verde beach to Cabeço beach is where, comparably, the coastline is more stable throughout the analysed time-frame. In this segment, a mean progradation rate (LRR) of $0.37 \mathrm{my}^{-1}$, with an average and maximum advance (NSM) of respectively, 23.8 and 30.3 is observed from 1950 to 2015 . An average SCE of $34.9 \mathrm{~m}$, with a maximum value of $41.6 \mathrm{~m}$, indicates that, although the SCE/NSM ratio points to an average oscillation is $46 \%$ higher than the NSM interval, the progradation is still low in terms of absolute values.

From this segment eastwards, the coastline position presents a higher accretion tendency, reaching values of up to $117 \mathrm{~m}$ of NSM, and rates (LRR) of $1.5 \mathrm{my}^{-1}$, at Monte Gordo, and a maximum NSM of $577 \mathrm{~m}$, and rates (LRR) of approximately $11 \mathrm{my}^{-1}$, near the Vila Real de Santo António jetty. Even though the jetty construction, between 1972 and 1974, favoured the seaward progradation of the coastline, this trend has been observed since 1870 , once that between 1870 and 1999, the coastline along the west bank of the estuary grew about $950 \mathrm{~m}$ and accumulated about $4.6 \times 10^{6} \mathrm{~m}^{3}$ of sediment (Gonzalez et al. 2001).

\section{Erosion and accretion areas}

As a result of the coastline displacement some sectors have gained area (Barreta and Armona islands, Cacela peninsula and Manta Rota - VRSA sector) while others have lost (Culatra, Tavira and Cabanas islands) (Table 3). Although the results cannot be interpreted as a sediment budget, because a volume analysis was not estimated, the resultant area gives an insight about the spatial variability of the coastal changes. Thus, the sum of the observed changes in each sector leads to total gain of area, for the entire system, of $1.05 \times 10^{6} \mathrm{~m}^{2}$.

\section{NSM and SCE comparison}

If coastline variation happens continuously in the same direction (retreat or progradation) during the time-period of analysis, NSM values are expected to be similar to SCE values. However, if coastline displacement, during the analysed time-period, is higher than the distance between the older and the most recent coastline, meaning that coastline evolution has shifted direction over time, then the SCE values are higher than the NSM. In these cases, the oscillation effect has to be taken into account to fully understand the coastal behaviour. 


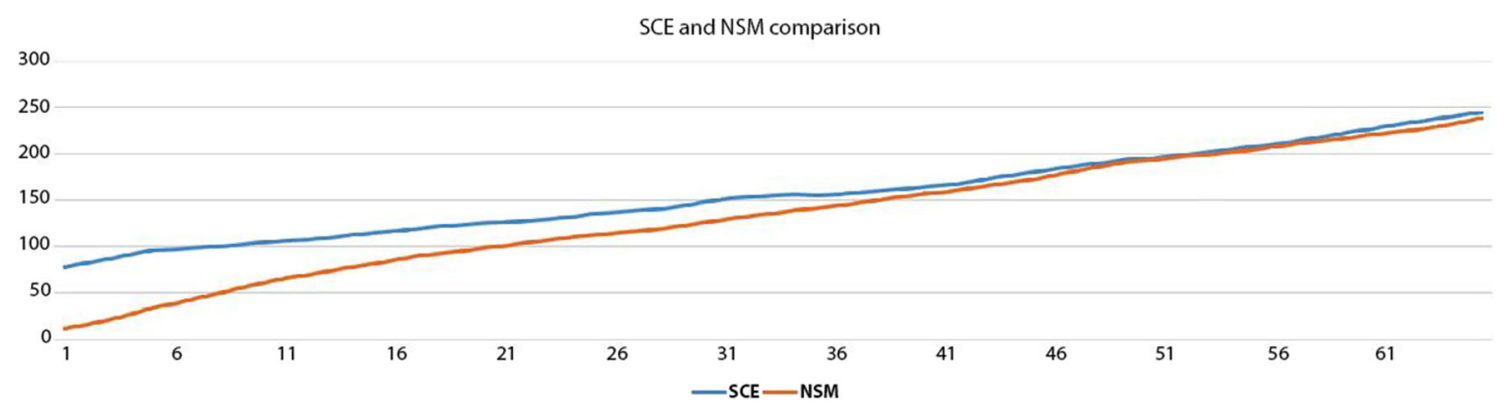

Fig. 12 Comparison between SCE and NSM in the second half of the Cacela peninsula sector. The difference is interpreted as a consequence of the recent erosion and the increment towards west is related with coastline

Looking at Fig. 11, the Cacela peninsula - VRSA sector is a good example of a coast with a well-defined trend of evolution (in this case, progradation) and where NSM properly defines the coastal changes. On the other hand, the Cabanas island provides a good example of when care should be taken whilst only using the NSM values to characterize the coastal behaviour. In other sectors, like the Tavira island or the Culatra island, a mixed situation occurs. Most of the SCE and NSM differences seems to be related to the longitudinal evolutionary pattern of the islands that, growing by the incorporation of spits, tend to generate larger SCE than NSM values. Other areas where NSM and SCE values are quite different are mainly explained by readjustments of the system due to inlet migration and coastline oscillations nearby fixed costal structures.

Cabanas island is a particular case in the system, due to the fact that the whole island was built during the study timeperiod and also because the new coastline shifted its direction over time, as it adapts to the remnant of the Cacela peninsula.

\section{Integrated natural versus artificial coastline evolution record}

The human interference in the coastal environment (jetty construction, inlet artificial opening or fixation, beach and dune re-nourishment, increased building of permanent structures, bathing sites and access footpaths and tractor paths through the dunes) changed the natural dynamics of the barrier islands system and its evolutionary behaviour, sometimes in opposite directions. Therefore, the obtained coastline evolution data do not represent the natural trend of the system, but instead, the composite coupling between the natural physical processes and human activities, the assessment of which is also critical, given the worldwide inevitable transformation of the coast into a human setting (Lazarus et al. 2016).

The progradational sectors in the barrier island complex are mostly connected to human interventions. The Faro inlet jetties were responsible for a substantial up-drift sand accumulation and a large seaward displacement of the coastline. It reorientation due to the Cacela inlet overture. Y axis: NSM and SCE; X axis: distance/10 along the coast. Units in meters

may be assumed that its influence may have spread further west, to the Santa Maria Cape and even the São Luís inlet. The erosion of the artificial nourishments of Falésia beach, westward of the study area, also contributed to the littoral drift increase and hence, it may also have contributed to the offshore shoreline displacement in the referred area. The same process may be assumed westwards of the Tavira inlet, with its jetties being responsible for an up-drift sand accumulation and a shoreline progradation along a $3000 \mathrm{~m}$ sector.

Although in a small sector, significant coastline progradation is also noticeable near the Armona inlet. Here, the beach growth occurs due to the sand accumulation related to the ebb-tidal delta growth, and hence, it takes the appearance of a natural evolution. However, the delta development is believed to occur due to a weakening of the inlet water flow, which happens due to the artificial Faro delta installation and maintenance.

Eastwards of Cacela peninsula, until VRSA, the obtained data shows a continuous, approximately $12 \mathrm{~km}$ long, coastal stretch with prograding behaviour. Westward VRSA jetty, beach growth is related to the up-drift accumulation resulting from the structure. However, from Manta Rota to Monte Gordo, sand accumulation and coastline seaward displacement is likely related to natural processes, namely the closure of the Manta Rota inlet, which occurred in the beginning of the last century, and the increase of the littoral drift due to the release of sand associated with the erosion of the former Cacela peninsula, where Cabanas island currently lies.

\section{Conclusions}

The current work brings new insights on the evolution of a continuous littoral fringe, from Ancão peninsula to Vila Real de Santo António, in the south of Portugal, an important and peculiar coastal sector with a very active barrier system flowed by a low-lying sandy coast. As part of a broader national programme at LNEG [https://geoportal.lneg.pt/mapa/? escala $=4000000 \&$ mapa $=$ geologiacosteira\#], this study achieves, for the first time, a long term (65-years) analyses 
of a high-resolution (10 m spaced) and systematic (approximately 10 years' interval) coastline evolution, using different sources of aerial imagery and USGS DSAS software to calculate shoreline displacement.

This methodology allowed for the production of data easily comparable to previously produced datasets, having the advantage, as a continuous and high-resolution dataset, of being a useful pack of information to support the planning and effective implementation, not only regional, but at local adaptive measures. Thus, the current results are not only valuable in a scientific perspective, as they improve the knowledge on a mesoscale evolutionary change of the Portuguese southeastern coast, but also in an applied way, as they constitute an important tool to contribute to support coastal managers and general users of littoral regions.

Regarding coastline movement, seaward displacement prevails within the $55 \mathrm{~km}$ coastal stretch, with a prograding coastline occupying approximately $54 \%$ of the studied sector. However, this progradation is mostly associated with human intervention on the coast, being related to up-drift accumulation against inlet jetties / groins and sand re-nourishment activities. The exception is the Manta Rota - Monte Gordo sector where accumulation is believed to occur mainly due to natural processes. Progradation occurs predominantly at the eastern and western limits of the study area. Maximum values were found near the Vila Real de Santo António jetty with values of $577 \mathrm{~m}$ of NSM, at a rate (LRR) of approximately $11 \mathrm{my}^{-1}$ and the Barreta island, with a maximum displacement of $365 \mathrm{~m}$, at a $5.8 \mathrm{my}^{-1}$ rate.

The erosional trend prevails predominantly in the central barrier island system, namely in the Culatra (with a maximum displacement of $-163 \mathrm{~m}$ ), Armona (with a maximum displacement of $-83 \mathrm{~m}$ ), the Tavira, (with a maximum displacement of $-116 \mathrm{~m}$ ), and the Cabanas islands, where the maximum erosion values were found, with NSM values of up to $-235 \mathrm{~m}$, and LRR of $-3.8 \mathrm{my}^{-1}$.

Regarding area changes, the NSM analysis indicates that some sectors lost and others gained area due to coastline displacement during the 65 -year period. However, the overall analysis allowed us to conclude that there was an area increase of $1.05 \times 10^{6} \mathrm{~m}^{2}$ for the south-eastern coastal fringe.

Considering the significant influence man-made interventions have on the coastline evolution, it is believed that the natural evolutionary pattern would point to an overall erosional trend in the islands sector and a progradational trend from Manta Rota to Vila Real de Santo António beach.

Supplementary Information The online version contains supplementary material available at https://doi.org/10.1007/s11852-020-00791-3.

Acknowledgements We acknowledge Direcção Geral do Território (DGT) and CiGEO (Army Geospatial Information Center) for providing orthophotos and the historical aerial photos. João Lopes and Vasco Silva, are greatly acknowledged for their enthusiasm and efficiency in dealing with DSAS software within the acquired and provided services by Synege. Câmara Municipal de Vila Real de Santo António and Câmara Municipal de Castro Marim are acknowledged for providing additional data, that were useful for this study.

We thank the reviewer's comments that helped improving the quality of the manuscript.

This work was financially supported by GPGE2020 project [POCI-020550-FEDER-022222] through Portugal 2020 and European Structural and Investment Funds from the European Union.

\section{References}

Andrade C (1998) Dynamics, erosion and conservation of beach areas. Commissariat of the Lisbon World Exposition, Lisboa, p 88

Andrade CF (1990) O Ambiente de Barreira da Ria Formosa (AlgarvePortugal). PhD thesis, University of Lisbon, pp 645

Ceia FR, Patrício J, Marques JC, Dias JA (2010) Coastal vulnerability in barrier islands: the high risk areas of the Ria Formosa (Portugal) system. Ocean Coast Manag 53:478-486. https://doi.org/10.1016/ j.ocecoaman.2010.06.004

Cooper JAG, Green AN, Loureiro C (2018) Geological constraints on mesoscale coastal barrier behaviour. Glob Planet Chang 168:15-34. https://doi.org/10.1016/j.gloplacha.2018.06.006

Costa CL (1994) Final report of sub-project a "wind wave climatology of the Portuguese coast". Instituto Hidrográfico, Lisboa, p 80

Dias JMA (1988) Aspectos geológicos do Litoral Algarvio. Geonovas 10: $113-128$

Dias JA, Taborda R (1992) Tidal gauge data in deducing secular trends of Relative Sea level and crustal movements in Portugal. J Coast Res 8(3):655-659

Dias JA, Taborda R (1998) Evolução recente do nível médio do mar em Portugal. Anais do Instituto Hidrográfico, vol 9:83-97

Dias JA, Ferreira Ó, Moura D (2004) O sistema de Ilhas-Barreira da Ria Formosa - Livro Guia da Excursão. Paper presented at the $3^{\circ}$ SIPRES - Simpósio Interdisciplinar sobre Processos Estuarinos. Maio 2014, Algarve, Portugal, pp 25-28

Esaguy AS (1984) Ria de Faro, Barra da Armona. Evolução 1873-1983. Direcção Geral de Portos, Lisboa, Portugal, p 5

Esaguy AS (1986) Ria de Faro. Barra de Faro-Olhão, Evolução $1955-$ 1985. Direcção Geral de Portos (Internal Report), Lisboa, Portugal, pp 10

Esaguy AS (1987) Ria de Faro. Barra de Tavira. Evolução. Direcção Geral de Portos, Lisboa, Portugal, p 13

Ferreira Ó, Dias JA, Taborda R (2008) Implications of sea-level rise for continental Portugal. J Coast Res 24(2):317-324

Ferreira Ó, Matias A, Pacheco A (2016) The East Coast of Algarve: a Barrier Island dominated coast. Thalassas: An Int J Mar Sci 32:7585. https://doi.org/10.1007/s41208-016-0010-1

Fletcher C, Rooney J, Barbeeh M, Lim S-C, Richmond B (2003) Mapping shoreline change using digital Orthophotogrammetry on Maui, Hawaii. J Coast Res SI 38:106-124

Fletcher CH, Romine BM, Genz AS, Barbee MM, Dyer M, Anderson TR, Lim S-C, Vitousek S, Bochicchio C, Richmond BM (2012) National assessment of shoreline change: Historical shoreline change in the Hawaiian Islands: U.S. Geological Survey Open-File Report 2011-1051, 55 p. (Also available at http://pubs.usgs.gov/of/ 2011/1051)

Garel E, Sousa C, Ferreira O (2015) Sand bypass and updrift beach evolution after jetty construction at an ebb-tidal delta. Estuar Coast Shelf Sci 167:4-13. https://doi.org/10.1016/j.ecss.2015.05.044

Gonzalez R, Dias J, Ferreira O (2001) Recent rapid evolution of the Guadiana estuary mouth (southwestern Iberian Peninsula). J Coast Res Proc Int Coast Symp 2000:516-527 
Hidroprojecto (1998) Plano de Ordenamento da Orla Costeira (Vilamoura-Vila Real de Santo António), vol 2. Estudos Complementares aos Estudos Base, Tomo I, p 27

Himmelstoss EA, Henderson RE, Kratzmann MG, Farris AS (2018) Digital Shoreline Analysis System (DSAS) version 5.0 user guide. US Geol Surv doi: https://doi.org/10.3133/ofr20181179

IPCC (2014) Climate change 2014: synthesis report. Contribution of working groups I. II and III to the Fifth Assessment Report of the Intergovernmental Panel on Climate Change, IPCC, Geneva, p 151

Lazarus ED, Ellis MA, Brad MA, Hall DM (2016) An evolving research agenda for human-coastal systems. Geomorphology 256:81-90. https://doi.org/10.1016/j.geomorph.2015.07.043

Lira CP, Silva AN, Taborda R, Andrade CF (2016) Coastline evolution of Portuguese low-lying sandy coast in the last 50 years: an integrated approach. Earth Syst Sci Data 8(1):265-278

Matias A (2006) Overwash sedimentary dynamics in the Ria Formosa barrier islands. $\mathrm{PhD}$ Thesis, University of Algarve, pp 274

McNamara DE, Lazarus ED (2018) Barrier Islands as coupled humanlandscape systems. In: Moore LJ, Murray AB (eds) Barrier dynamics and response to changing climate. Springer International Publishing, Cham, pp 363-383. https://doi.org/10.1007/978-3-31968086-6_12

Morales JA (1997) Evolution and facies architecture of the mesotidal Guadiana River delta (S.W. Spain - Portugal). Mar Geol 138:127148. https://doi.org/10.1016/S0025-3227(97)00009-1

Nave S, Rebêlo L (2018) High-resolution geological cartography and coastal evolution assessment at Armação de Pêra - Galé sector: a prototype for a national coastal mapping. J Coast Conserv 22:10311043. https://doi.org/10.1007/s11852-018-0612-2

Niedoroda AW, Swift DJP, Hopkins TS (1985) The shoreface. In: Davies RA (ed) Coastal sedimentary environments. Springer-Verlag, New York, pp 533-624

Oyedotun TDT (2014) Shoreline geometry: DSAS as a tool for historical trend analysis. Geomorphological techniques, chap. 3, sec. 2.2. British Society for Geomorphology, London, pp 12

Pilkey OH, Neal WJ, Monteiro JH, Dias JMA (1989) Algarve Barrier Islands: a noncoastal-plain system in Portugal. J Coast Res 5:239 261

Pinto CA, Silveira TM, Teixeira SB (2018) Alimentação artificial de praias na faixa costeira de Portugal Continental: Enquadramento e retrospetiva das intervenções realizadas (1950-2017). Relatório Técnico. Agência Portuguesa do Ambiente, pp 60

Rebêlo L (2004) Evolução e Dinâmica dos Sistemas Dunares da Manta Rota e do Guincho Oitavos: Dois Sistemas Distintos na Evolução das Dunas Costeiras em Portugal. Dissertação referente às provas de acesso à categoria de Investigador Auxiliar do Instituto Geológico e Mineiro, Lisboa, p 256
Rebêlo LP, Nave S (2018) Variações da linha de costa devido à abertura de uma barra artificial no sistema de Ilhas-barreira da Ria Formosa. In: X Congresso Nacional de Geologia. Açores. Vulcânica, Revista Portuguesa de Vulcanologia, pp 379-380

Rebêlo L, Nave S (2019) Manual de Utilizador para Execução da Determinação da Perigosidade Costeira à Escala 1: 3.000. Procedimentos Técnicos, versão 1. LNEG, Alfragide, Portugal, 7pp

Salles P (2001) Hydrodynamic controls on multiple tidal inlet persistence. $\mathrm{PhD}$, Massachusetts Institute of Technology and Woods Hole Oceanographic Institution, $266 \mathrm{pp}$.

Schmidt L, Prista P, Saraiva T, O'Riordan T, Gomes C (2013) Adapting governance for coastal change in Portugal. Land Use Policy 31:314 325. https://doi.org/10.1016/j.landusepol.2012.07.012

Teixeira SB (2009) Demarcação do Leito e da Margem das Águas do Mar no Litoral Sul do Algarve. Internal Report. Administração da Região Hidrográfica do Algarve, Faro, Portugal pp 207

Vila-Concejo A, Ferreira Ó, Morris BD, Matias A, Dias JMA (2002) Lessons from inlet relocation: examples from southern Portugal. Coast Eng 51:967-990. https://doi.org/10.1016/j.coastaleng.2004. 07.019

Vila-Concejo A, Matias A, Pacheco A, Ferreira Ó, Dias JA (2006) Quantification of inlet-related hazards in barrier island systems. An example from the Ria Formosa (Portugal). Cont Shelf Res 26:10451060. https://doi.org/10.1016/j.csr.2005.12.014

Vousdoukas MI, Ranasinghe R, Mentaschi L, Plomaritis TA, Athanasiou P, Luijendijk A, Feyen L (2020) Sandy coastlines under threat of erosion. Nat Clim Chang 10:260-263. https://doi.org/10.1038/ s41558-020-0697-0

Waelbroeck C, Labeyrie L, Michel E, Duplessy JC, McManus JF, Lambeck K, Balbon E, Labracherie M (2002) Sea-level and deep water temperature changes derived from benthic foraminifera isotopic records. Quat Sci Rev 21:295-291. https://doi.org/10.1016/ S0277-3791(01)00101-9

Weinholtz MB (1964) Contribuição para o estudo da evolução das flechas de areia na costa sotavento do Algarve (Ria de Faro). Boletim trimestral de Informação da Direcção-Geral de Serviços Hidráulicos, pp 14

Weinholtz MB (1978) Contribuição para o estudo da evolução das flechas de areia na costa sotavento do Algarve (Ria de Faro). Relatório da Direcção Geral de Portos, Lisboa, Portugal

Woodroffe CD (2002) Coasts: form, process and evolution. Cambridge University Press, Cambridge and New York, pp 623

Publisher's note Springer Nature remains neutral with regard to jurisdictional claims in published maps and institutional affiliations. 